Historic, Archive Document

Do not assume content reflects current scientific knowledge, policies, or practices. 



\section{TRADE LIST}

\section{Spring, 1913}

CUSTOMERS are requested to state the mode of conveyance by which they desire their trees forwarded. When no route is named, we forward to the best of our judgment, without liability for error or delay.

RESPONSIBILITY.-After goods are placed on board cars here, we assume no responsibility for their safe or prompt delivery, or any injury caused by delay in delivery by the transportation company.

ALL CLAIMS must be made upon receipt of goods.

TERMS CASH, on or before delivery to express or railroad agents, unless by special arrangement.

Two hundred and fifty, twenty-five or five of any one variety will be furnished by the thousand, hundred and ten rates, respectively, but single plants of one or more varieties will not be sold at less than 15 cents each, except Vines and Herbaceous Plants, the minimum price of which will be 10 cents each.

PACKING CHARGED EXTRA, but only sufficient to cover cost of time and material consumed in the work.

POST OFFICE ORDERS payable at Dresher P. O., Montgomery $\mathrm{Co}, \mathrm{Pa}$.

WESTERN UNION TELEGRAPH, AMBLER, PA. Use Nurserymen's Telegraphic Code or "A B C" Code, 4th edition.

VISITORS are always welcome and should take train at the Reading Terminal, 12th and Market Streets, Philadelphia, for Camp Hill Station, or at Broad Street Station, Pennsylvania R. R., for Fort Hill Station. Be sure that the train stops at these stations.

NOTICE.-It is necessary that you should TELEPHONE us (Bell Phone, 226-A Ambler; Keystone Phone, Jenkintown 652-Y), in advance of your coming, so that we can send a carriage to the station for you. Our office is $21 / 2$ miles from either station.

\section{CERTIFICATE OF INSPECTION}

Our nurseries are inspected several times each year, by inspectors of the Entomological Division of the Department of Agriculture of the State of Pennsylvania, and are free from insect pests and diseases. A certificate of the Department is attached to all shipments, and will also be furnished to customers if desired. 


\section{Hiel Yt. Yaras Deciduous Trees}

Several years ago we realized that there would shortly be a demand for a better grade of shade trees than were being commonly sold in nurseries at that time. With this idea in mind we commenced transplanting large blocks of all varieties, selecting only nice, straight, first-class trees for the purpose, discarding any crooked or ill-shaped stock. Time has proven the wisdom of our foresight, and while the demand for this class of stock has been greater than our expectation, our supply has been sufficient to meet the demand, and though our sales last year on these trees were very heavy, we still have a good supply on hand for this season's sales.

Our object is to grow a first-class tree, well rooted, with straight trunk and a nice top, and we spare no expense to produce a tree of this character. All crooked trees are discarded. Every tree we send out is a good tree. We stake all of our trees with long bamboo poles, and in that way we get not only a perfectly straight trunk, but a stem right to the top of the tree. This should be kept in mind " when comparing our prices with the "cheap" trees usually offered.

Acer campestre, English Cork Maple

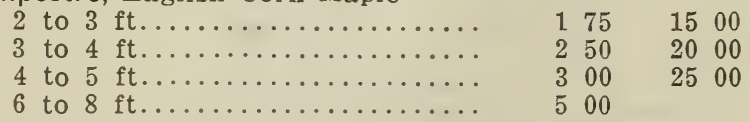

dasycarpum, Silver Maple

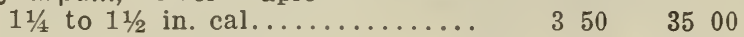

$1 \frac{1 / 2}{2}$ to $1 \frac{3 / 4}{4}$ in. cal........... $500 \quad 4500$

“ dasycarpum Weirii, Weir's Cut-leaf Maple

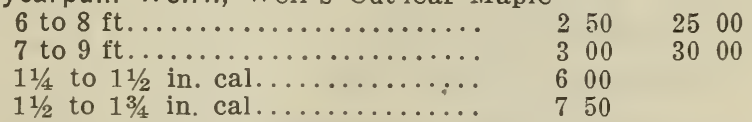

" negundo, Ash-leaved Maple, Box Elder

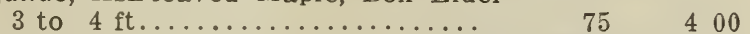

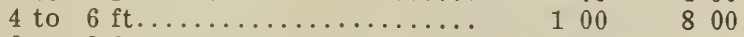

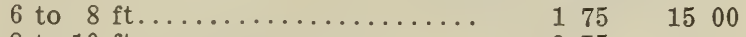

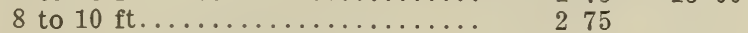

“Pennsylvanicum (Striatum)

2 to $3 \mathrm{ft} \ldots \ldots \ldots \ldots \ldots \ldots \ldots \ldots \ldots$

3 to $4 \mathrm{ft} . \ldots \ldots \ldots \ldots \ldots \ldots \ldots \ldots .200$

platanoides, Norway Maple

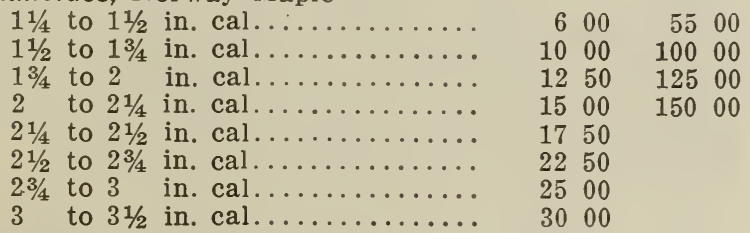

" platanoides Reitenbachi, Purple-leaved Norway Maple

2 to $2 \frac{1}{4}$ in. cal............. 2000 
Per 10 Per 10()
8 to $10 \mathrm{ft} .1$ to $11 / 4$ in. cal......

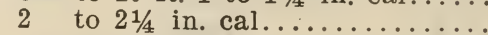
1750
2000
$21 / 2$ to $23 / 4$ in. cal............. 2250
2 to $21 / 4$ in. cal. specimen..... 2250
$2 \frac{1}{4}$ to $2 \frac{1}{2}$ in. cal. specimen...... 2500
$21 / 2$ to $23 / 4$ in. cal. specimen..... 2750

" platanoides globosa, Globe-headed Norway Maple

. 4 to $6 \mathrm{ft}$. stems.................... 1500

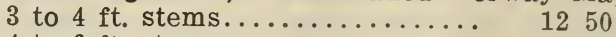

pseudo-platanus, Sycamore Maple
4 to $5 \mathrm{ft} . \ldots \ldots \ldots \ldots \ldots \ldots \ldots$
175
$200-1700$

“ pseudo-purpurea, Purple-leaved Sycamore Maple
$11 / 2$ to 2 in. cal............. 750
2 to $2 \frac{1 / 4}{4}$ in. cal.................. 1500
$21 / 4$ to $2 \frac{1}{2}$ in. cal............. 1750
$21 / 2$ to $23 / 4$ in. cal................. 2000
$23 / 4$ to 3 in. cal............... 2250
3 to $3 \frac{1}{2}$ in. cal............. 2500

“ rubrum, Red Maple
3 to $4 \mathrm{ft} . \ldots \ldots \ldots \ldots \ldots \ldots \ldots$
4 to $6 \mathrm{ft} \ldots \ldots \ldots \ldots \ldots \ldots \ldots$
250
350

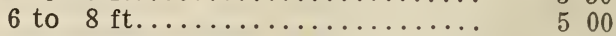
" saccharum, Sugar or Rock Maple
750
2000

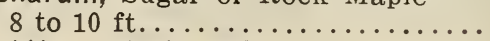

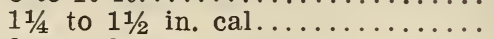

600

2 to $2 \frac{1 / 4}{4}$ in. cal............. 1750

$21 / 4$ to $21 / 2$ in. cal............. 2000

$11 / 4$ to $1 \frac{1}{2}$ in. cal. specimens.... 1250

$11 / 2$ to $13 / 4$ in. cal. specimens.... 1500

$13 / 4$ to 2 in. cal. specimens.... 1750

2 to $2 \frac{1}{4}$ in. cal. specimens..... 2000

" saccharum nigrum, Black Sugar Maple

3 to $4 \mathrm{ft} . \ldots \ldots \ldots \ldots \ldots \ldots \ldots \ldots$

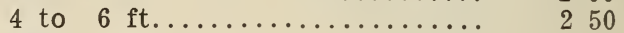

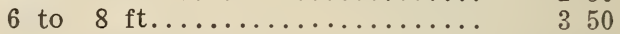

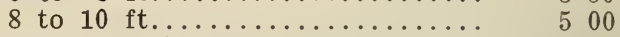

$13 / 4$ to 2 in. cal............ 1500

2 to $21 / 4$ in. cal............... 2000

" spicatum, Mountain Maple

\begin{tabular}{|c|c|c|c|}
\hline to 3 & ft........... & 200 & \\
\hline to 4 & $\mathrm{ft} . \ldots \ldots \ldots \ldots \ldots \ldots \ldots \ldots$ & 250 & \\
\hline $\begin{array}{l}4 \text { to } 5 \\
\text { aricum }\end{array}$ & ft..................... & 350 & \\
\hline 2 to 3 & ft....... & 150 & \\
\hline to 4 & $\ldots \ldots \ldots \ldots$ & 175 & 15 \\
\hline to 5 & $\mathrm{ft} \ldots \ldots \ldots \ldots \ldots$ & 250 & 20 \\
\hline
\end{tabular}

\section{Japanese Maples}

Why buy cheap imported Japanese Maples, hide-bound stock, poorly rooted, varieties badly mixed up and untrue to name, when you can buy healthy American-grown plants well rooted, vigorous and well-developed tops, guaranteed true to name and at a price very little higher than the imported stuff. All of our Japanese Maples are propagated in our nurseries and are guaranteed true to name.

Acer Japonicum, Green-leaved

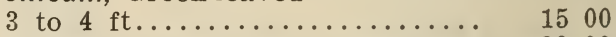

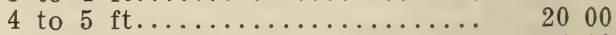

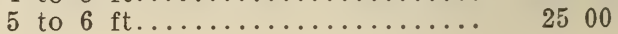


. Japonicum aconitifolium, Green-leaved
2 to $3 \mathrm{ft} . \ldots \ldots \ldots \ldots \ldots \ldots . \ldots . \ldots$
3 to $4 \mathrm{ft} . \ldots \ldots \ldots \ldots \ldots \ldots \ldots \ldots$

- Japonicum palmatum, Green-leaved

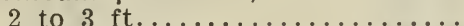

3 to $4 \mathrm{ft} . \ldots \ldots \ldots \ldots \ldots \ldots \ldots \ldots . \ldots \ldots$

4 to $5 \mathrm{ft} . \ldots \ldots \ldots \ldots \ldots \ldots \ldots . \ldots 200$

- polymorphum, Green-leaved

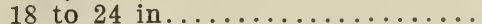
2 to $3 \mathrm{ft} . \ldots \ldots \ldots \ldots \ldots \ldots \ldots$
400
3 to $4 \mathrm{ft} . \ldots \ldots \ldots \ldots \ldots \ldots \ldots$
650
4 to $5 \mathrm{ft} . \ldots \ldots \ldots \ldots . . . . . . .$.
1000

. polymorphum ampelopsilobum, Green-leaved
2 to $3 \mathrm{ft} . \ldots \ldots \ldots \ldots \ldots \ldots \ldots . \ldots \ldots 10 . \ldots \ldots$
3 to $4 \mathrm{ft} \ldots \ldots \ldots \ldots \ldots \ldots \ldots \ldots \ldots . \ldots \ldots$
4 to $5 \mathrm{ft} . \ldots \ldots \ldots \ldots \ldots \ldots . \ldots . \ldots 200$

“ polymorphum atropurpureum, Blood-leaved

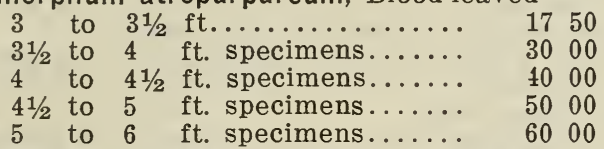

" polymorphum cristatum, Green Fern-leaved

2 to $21 / 2$ ft.......................... 1000

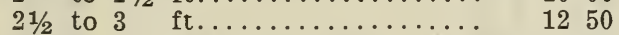

“. polymorphum dissectum, Green Cut-leaved

$31 / 2$ to 4 ft. specimens........ 3000

4 to $4 \frac{1}{2} \mathrm{ft}$. specimens......... 4000

" polymorphum dissectum atropurpureum, Purple Cutleaved
$21 / 2$ to 3
$\mathrm{ft} . \ldots \ldots \ldots \ldots \ldots \ldots$
1500

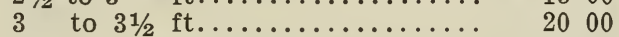
$31 / 2$ to 4 ft. specimens........... 3000
4 to 5 ft. specimens........ 4000

" polymorphum pinnatifolium atropurpureum, Purple lance-leaved

$21 / 2$ to $3 \mathrm{ft} . \ldots \ldots \ldots \ldots \ldots \ldots \ldots . \ldots \ldots$

3 to $4 \mathrm{ft} . \ldots \ldots \ldots \ldots \ldots \ldots . \ldots . \ldots 200$

“polymorphum reticulatum, Green and Yellow Variegated leaved

18 to 21 in.................. 1000

“polymorphum sanguineum, Purple-leaved

3 to $4 \mathrm{ft} . \ldots \ldots \ldots \ldots \ldots \ldots \ldots . \ldots \ldots$

4 to 5 ft..................... 2000

Aesculus hippocastaneum, Eu. Horse Chestnut

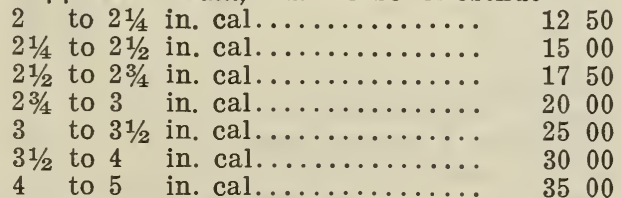

“ hippocastaneum alba plena, Double White Flowered
$13 / 4$ to 2 .
in. cal..
850
2 to $2 \frac{1}{4}$ in. cal............. 1350

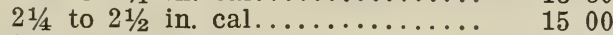
$2 \frac{1}{2}$ to $23 / 4$ in. cal....................... 1750

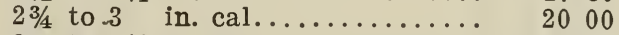
3 to $3 \frac{1}{2}$ in. cal.............. 2500
$31 / 2$ to 4 in. cal........... 3000 
" rubicunda Briotti, Red Flowering Horse Chestnut

Per 10 Per 100

$12 \mathrm{ft} .2 \frac{1}{2}$ to 3 in. cal.......... 2500

" glabra, Ohio Buck-eye

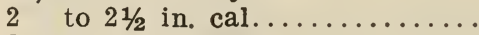
1250

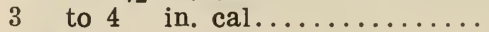
2500

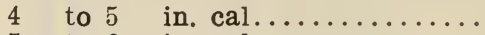
5 to 6 in. cal...............
3000
4000

Ailanthus glandulosa, Tree of Heaven
3 to $4 \mathrm{ft} . \ldots \ldots \ldots \ldots \ldots \ldots \ldots$
150

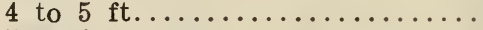
5 to $6 \mathrm{ft} . \ldots \ldots \ldots \ldots \ldots \ldots \ldots \ldots$
175
1250
1500
250
2000

Amygdalus Persica (see Prunus Persica)

Aralia (see Shrubs)

Betula alba, Eu. White Birch
3 to $4 \mathrm{ft} . \ldots \ldots \ldots \ldots \ldots \ldots$
4 to $5 \mathrm{ft} \ldots \ldots \ldots \ldots \ldots \ldots \ldots \ldots$
5 to $6 \mathrm{ft} \ldots \ldots \ldots \ldots \ldots \ldots \ldots$
6 to $8 \mathrm{ft} \ldots \ldots \ldots \ldots \ldots \ldots \ldots \ldots$

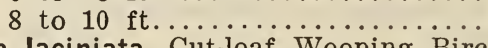

" alba laciniata, Cut-leaf Weeping Birch
6 to $8 \mathrm{ft} . \ldots \ldots \ldots \ldots \ldots \ldots \ldots$

8 to $10 \mathrm{ft} \ldots . . .$.

- lenta, Sweet Birch

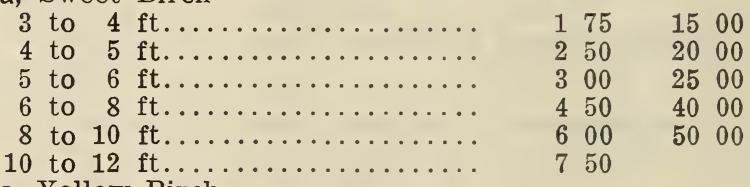

- Iutea, Yellow Birch
3 to $4 \mathrm{ft} . \ldots \ldots \ldots \ldots \ldots \ldots$.
$\begin{array}{llll}175 & 15 & 00\end{array}$
4 to $5 \mathrm{ft} . \ldots \ldots \ldots \ldots \ldots \ldots \ldots \ldots \ldots \ldots \ldots \ldots \ldots$
6 to $8 \mathrm{ft} . \ldots \ldots \ldots \ldots \ldots \ldots \ldots \ldots$
8 to $10 \mathrm{ft} . \ldots \ldots \ldots \ldots \ldots \ldots$.
300
2500

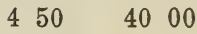

- papyracea, Paper Birch

\begin{tabular}{|c|c|c|c|}
\hline 3 to 4 & $\mathrm{ft}, \ldots \ldots \ldots \ldots \ldots \ldots$ & 175 & 1500 \\
\hline to & $\mathrm{ft}, \ldots \ldots \ldots \ldots \ldots \ldots \ldots$ & 250 & 2000 \\
\hline to & ft.... & 350 & $30 \quad 00$ \\
\hline to 8 & ft.... & 450 & $40 \quad 00$ \\
\hline to 10 & $\cdots \cdots$ & 600 & 5000 \\
\hline
\end{tabular}

- populifolia, Poplar Birch

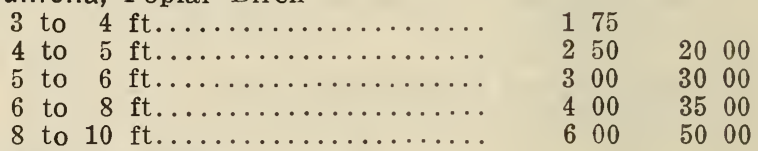

- rubra (nigra), Red or Water Birch

10 to $12 \mathrm{ft} . \ldots \ldots \ldots \ldots \ldots \ldots \ldots$

12 to $14 \mathrm{ft} . \ldots \ldots \ldots \ldots \ldots \ldots$

14 to $16 \mathrm{ft} . \ldots \ldots \ldots \ldots \ldots \ldots \ldots$

Carpinus, Hornbeam (see Shrubs)

Catalpa Bungeii, Standard

2 yr. heads 6 to $8 \mathrm{ft}$. stems..... 600

“ Kaempferi, Japanese

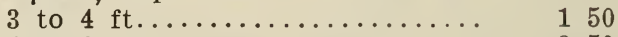

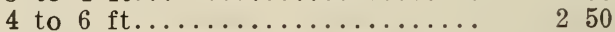

6 to $8 \mathrm{ft} \ldots \ldots \ldots \ldots \ldots \ldots \ldots . . . . .250$

" speciosa, Western Catalpa

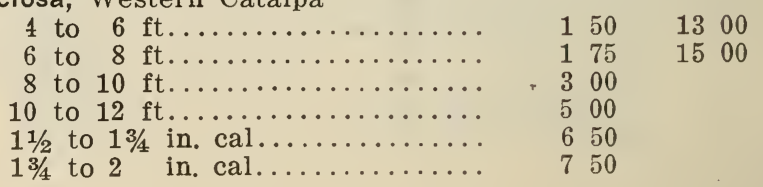


Per 10 Per 100

Cedrelia sinensis

\begin{tabular}{|c|c|c|c|}
\hline & & & \\
\hline to & $\ldots \ldots \ldots$ & 175 & 1500 \\
\hline to & $\mathrm{ft}$. & 250 & \\
\hline & $\mathrm{ft}$ & 350 & 3000 \\
\hline 1 & $\mathrm{ft}$ & 500 & $40 \quad 00$ \\
\hline & $\ldots \ldots$ & 1000 & 75 \\
\hline
\end{tabular}

Celtis sinensis, Chinese Hack-berry

3 to $4 \mathrm{ft} . \ldots \ldots \ldots \ldots \ldots \ldots \ldots . \ldots \ldots$

4 to $5 \mathrm{ft} . \ldots \ldots \ldots \ldots \ldots \ldots \ldots . \ldots \ldots$

Cerasus Japonica alba fl. pl., Double White Cherry

3 to $4 \mathrm{ft} . \ldots . \ldots \ldots \ldots . . \ldots . . .60$

- Japonica rosea fl. pl., Double Pink Cherry

3 to $4 \mathrm{ft} . \ldots \ldots \ldots \ldots \ldots \ldots . \ldots . \ldots . \ldots$

“Japonica rosea pendula, Weeping Rose Cherry

2 -year heads ............... 750

"Padus, European Bird Cherry

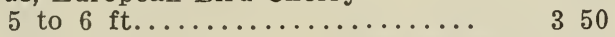

Cercidiphyllum Japonicum

8 to $10 \mathrm{ft} . \ldots \ldots \ldots \ldots \ldots \ldots . \ldots . \ldots 1250 \quad 100 \quad 00$

Cercis Canadensis and Japonica (see Shrubs)

Cornus florida (see Shrubs)

Crataegus (see Shrubs)

Dimorpanthus Mandschurica (see Aralia Mandschurica)

Fagus sylvatica, European Beech

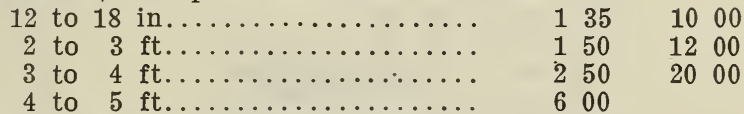

asplenifolia, Fern-leaved

18 to 24 in................ 400

“ pendula, Weeping Beech

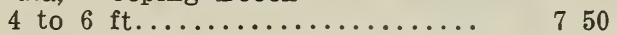

“ purpurea, Copper Beech

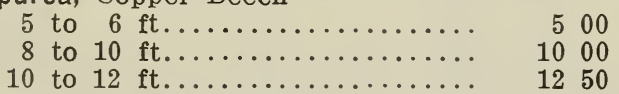

" River's Blood-leaf Beech

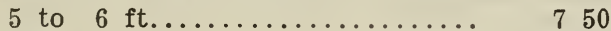

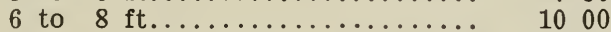

8 to $10 \mathrm{ft}$. specimens.......... 2000

Fraxinus Americana, American White Ash

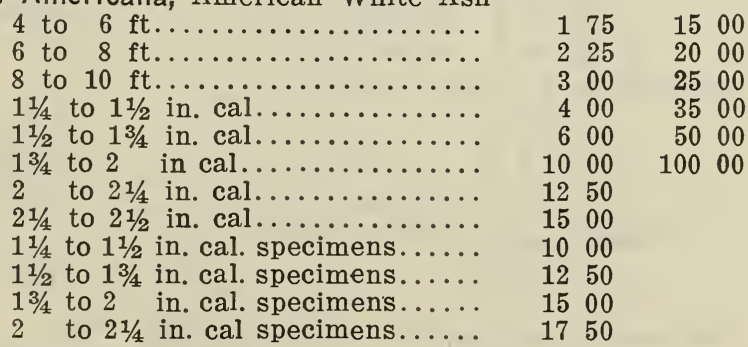

"Americana acubaefolia

8 to $10 \mathrm{ft}$., $1 \frac{1 / 2}{2}$ to 2 in. cal.... 1000

10 to $12 \mathrm{ft} ., 2$ to $21 / 4$ in. cal.... 1500

“ excelsior, English Ash

8 to $10 \mathrm{ft} . \ldots \ldots \ldots \ldots \ldots \ldots . .350$

$11 / 4$ to $11 / 2$ in. cal............. 400

$11 / 2$ to 2 in. cal............. 750

2 to 3 in. cal............ 1250 
“ excelsior heterophylla

8 to $10 \mathrm{ft}$., $1 \frac{1 / 2}{2}$ to 2 in. cal...... 1500

“ Mandschurica

$1 \frac{1}{2}$ to 2 in. cal.............. 1000

“pubescens, Red Ash

8 to $10 \mathrm{ft}$., 2 to $2 \frac{1}{2}$ in. cal.... 1500

10 to $12 \mathrm{ft} ., 2 \frac{1}{2}$ to 3 in. cal.... 2000

“ quadrangulata, Blue Ash

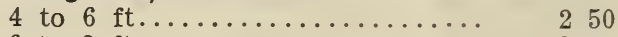

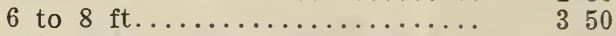

$1 \frac{1 / 2}{2}$ to 2 in. cal................ 750

" sambucifolia, Black Ash

6 to $8 \mathrm{ft} . . . \ldots \ldots \ldots \ldots \ldots \ldots$

350

500

3000

8 to $10 \mathrm{ft} . \ldots \ldots \ldots \ldots \ldots \ldots \ldots \ldots$.

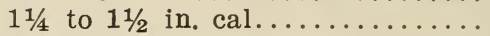

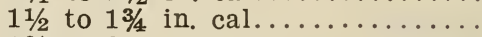

650

750

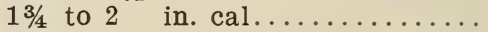

1250

“ viridis, Green Ash

6 to $8 \mathrm{ft} . \ldots \ldots \ldots \ldots \ldots \ldots$

$\begin{array}{llll}175 & 1500\end{array}$

8 to $10 \mathrm{ft} . \ldots \ldots \ldots \ldots \ldots \ldots \ldots$

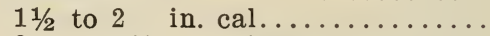

250

500

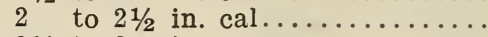

1250

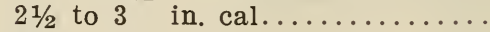

$11 / 4$ to $1 \frac{1}{2}$ in cal. specimen..........

$1 \frac{1}{2}$ to $1 \frac{13}{4}$ in. cal. specimen......

$13 / 4$ to 2 in. cal. specimen.....

1500

750

1000

2 to $2 \frac{1}{4}$ in. cal. specimen..... 1500

Ginkgo (see Salisburia)

Gleditschia triacanthos, Honey Locust

\begin{tabular}{|c|c|c|c|}
\hline to 4 & $\mathrm{ft} \ldots \ldots \ldots \ldots \ldots$ & & 75 \\
\hline 6 & $\ldots \ldots \ldots \ldots \ldots$ & & \\
\hline 8 & $\mathrm{ft}$ & & 50 \\
\hline 10 & $\mathrm{ft}$ & 6 & 00 \\
\hline 12 & $\ldots \ldots \ldots \ldots \ldots \ldots \ldots$ & 10 & \\
\hline
\end{tabular}

Gymnocladus canadensis, Kentucky Coffee Tree

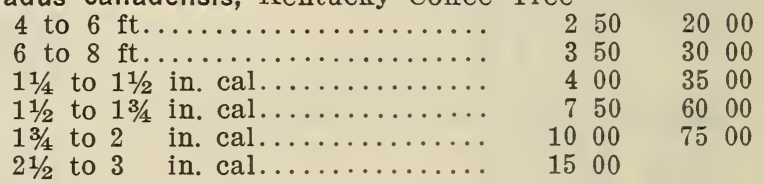

Juglans nigra, Black Walnut

2 to $3 \mathrm{ft} . \ldots \ldots \ldots \ldots \ldots \ldots$

$135 \quad 1200$

3 to $4 \mathrm{ft} . \ldots \ldots \ldots \ldots \ldots \ldots \ldots \ldots$

4 to $6 \mathrm{ft} . \ldots \ldots \ldots \ldots \ldots \ldots \ldots \ldots$

6 to $8 \mathrm{ft} . \ldots \ldots \ldots \ldots \ldots \ldots \ldots$

$\begin{array}{llll}175 & 1500\end{array}$

$250 \quad 2000$

$350 \quad 2500$

“ regia, English Walnut, Madera Nut
2 to $3 \mathrm{ft} . \ldots \ldots \ldots \ldots \ldots \ldots$
6 to $8 \mathrm{ft} \ldots \ldots \ldots \ldots \ldots \ldots \ldots$
$135 \quad 1200$
$\begin{array}{llll}4 & 00 & 35 & 00\end{array}$

Koelreuteria paniculata, Japanese Varnish Tree

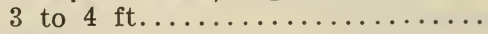
200
1800
5 to $6 \mathrm{ft} . \ldots \ldots \ldots \ldots \ldots \ldots \ldots$
350
$30 \quad 00$
6 to $8 \mathrm{ft} . \ldots \ldots \ldots \ldots \ldots \ldots . . . . . .$.
500
4000

Larix Europaea, European Larch

3 to $4 \mathrm{ft} . \ldots \ldots \ldots \ldots \ldots \ldots \ldots \ldots . \ldots 175 \quad 1500$

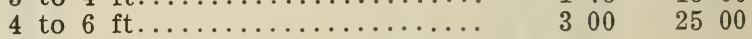

“ Kaempferi, Japanese Larch

5 to $6 \mathrm{ft} . \ldots \ldots \ldots \ldots \ldots \ldots \ldots$ 
Liquidambar styraciflua, Sweet Gum

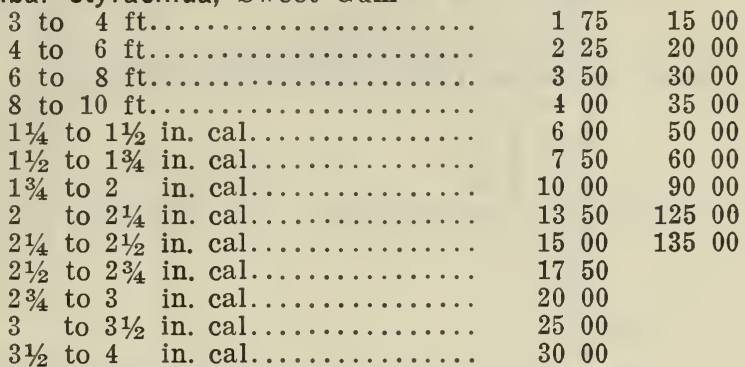

Liriodendron tulipifera, Tulip Tree

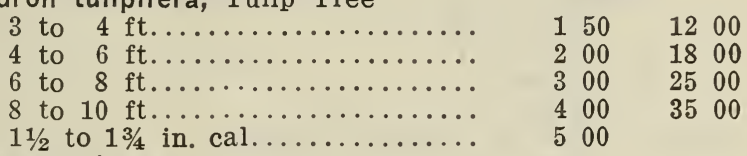

Magnolia acuminata

3 to $4 \mathrm{ft} . \ldots \ldots \ldots \ldots \ldots \ldots \ldots \ldots$

4 to $5 \mathrm{ft} . \ldots \ldots \ldots \ldots \ldots \ldots \ldots \ldots$

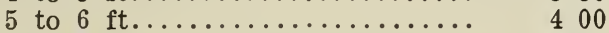

6 to $8 \mathrm{ft} . \ldots \ldots \ldots \ldots \ldots \ldots \ldots .600$

\section{Magnolias}

\section{Large Flowered Chinese Varieties}

The following Magnolias have been several times transplanted. They are very bushy plants, branched to the ground. They will be dug with ball of earth and the ball sewed in burlap.

Magnolia Alexandrina, White, pink centre

2 to $2 \frac{1}{2} \mathrm{ft}$. with ball......... 750

$21 / 2$ to 3 ft. with ball........ 1000

" conspicua, Chinese White Magnolia

6 to $8 \mathrm{ft} . \ldots \ldots \ldots \ldots \ldots \ldots . . .200$

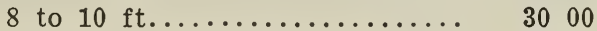

10 to $12 \mathrm{ft} . \ldots \ldots \ldots \ldots \ldots \ldots . \quad 4000$

“ gracilis, Chinese Purple Flower

18 to 24 in. with ball.......... 500

2 to $3 \mathrm{ft}$. with ball.......... 750

3 to $4 \mathrm{ft}$. with ball.......... 1000

" Halleana (see Stellata)

" hypoleuca, Japanese Magnolia

4 to $5 \mathrm{ft}$. with ball........... 1500

“ Lennei, Large Purple Flowered

$21 / 2$ to $3 \mathrm{ft}$. with ball......... 1000

“ purpurea, Purple

18 to 24 in. with ball......... 500

2 to $3 \mathrm{ft}$. with ball.......... 750

3 to $4 \mathrm{ft}$. with ball.......... 1000

4 to $5 \mathrm{ft}$. with ball........... 1250

5 to $6 \mathrm{ft}$., large clumps.......... 2000

“Soulangeana, Large Pink Flowered Magnolia

2 to $3 \mathrm{ft}$. with ball........... 750

3 to $4 \mathrm{ft}$. with ball................ 1000

4 to $5 \mathrm{ft}$. with ball........... 1250

" speciosa, Early Pink Flowered Magnolia

2 to $3 \mathrm{ft}$. with ball............ 750 
- stellata (Halleana), Hall's White Star Flowered

18 in. with ball............. 750

$21 / 2$ to $3 \mathrm{ft}$. with ball.......... 1250

$6 \mathrm{ft}$. specimens, with ball....... $50 \quad 00$

Malus coronaria (Pyrus), Sweet Scented Crab
2 to $3 \mathrm{ft} . \ldots \ldots \ldots \ldots \ldots \ldots \ldots \ldots$

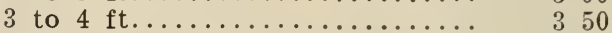
2500

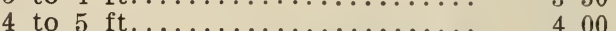
3000
3500

" floribunda atrosanguinea, Pink Flowering Crab

"Kiado
4 to $5 \mathrm{ft} . \ldots \ldots \ldots \ldots \ldots \ldots . \ldots . \ldots . \ldots$

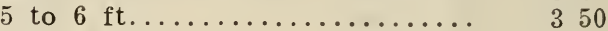
6 to $8 \mathrm{ft} \ldots \ldots \ldots \ldots \ldots \ldots \ldots \ldots \ldots$

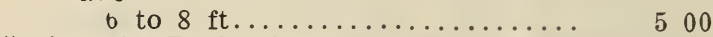

" loensis, Bechtel's Double Flowering Crab

18 to 24 in................. 200

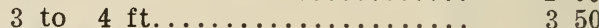

"Scheideckeri

$$
4 \text { to } 5 \text { ft................. } 350
$$

Morus Tartarica, Russian Mulberry

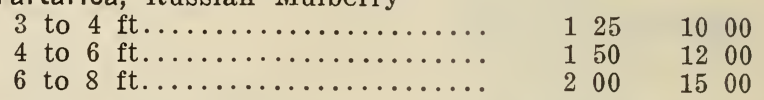

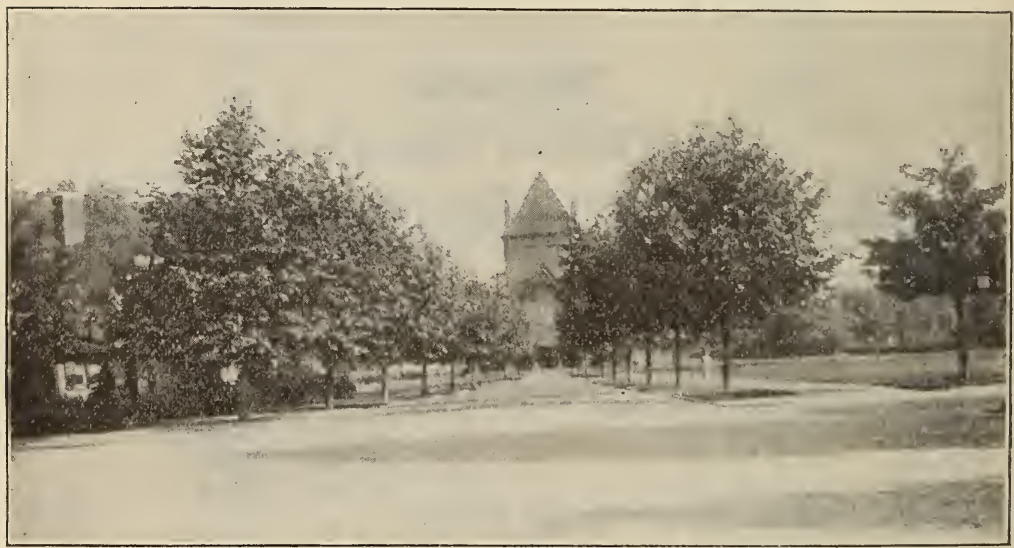

\section{Platanus Orientalis European Plane or Sycamore}

One of the fastest growing shade trees, in great demand for street planting. It makes a large tree of regular growth of top.

We have a lot of very fine trees in the sizes quoted in catalogue. Our trees have straight trunks, and are mostly branched five to seven feet from the ground, according to the size of the tree offered.

\section{Specimen Oriental Planes}

We still have about one hundred specimen Oriental Planes unsold. They are from 15 to 20 feet tall, perfectly straight stems, with trunks $23 / 4$ to 3 inch, and 3 to $3 \frac{1}{2}$ inch calliper, are branched about 8 feet from the ground. They have been growing I 2 feet apart each way and have large well developed heads. They are too large to be packed in bales and can only be shipped in car lots. See prices under head of "Specimen Shade Trees." 


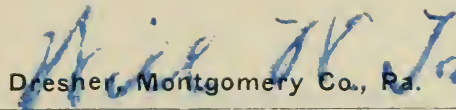

“ Tea's Weeping Mulberry

2 year heads................ 600

3 year heads............... 750

4 year heads very large and heavy $\quad 10 \quad 00$

Negundo aceroides (see Acer negundo)

Ostrya Virginica

3 to $4 \mathrm{ft} . \ldots \ldots \ldots . . . . . . .500$

Oxydendron arboreum, Sorrel Tree

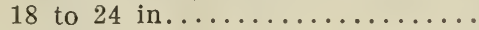

2 to $3 \mathrm{ft} \ldots \ldots \ldots \ldots \ldots \ldots \ldots$.

250

350

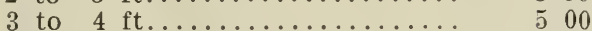

4 to $5 \mathrm{ft} \ldots \ldots \ldots \ldots \ldots \ldots \ldots . \ldots 60$

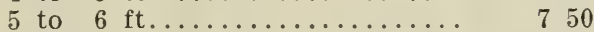

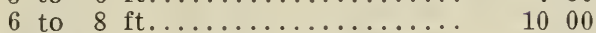

2000

3500

Paulownia Imperialis, Empress Tree

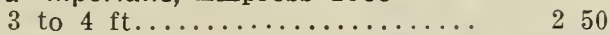

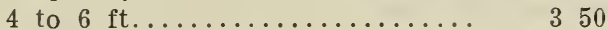

$30 \quad 00$

Pavia flava, Yellow Buck-eye

3 to $4 \mathrm{ft} . \ldots \ldots \ldots \ldots \ldots \ldots \ldots \ldots \ldots$

1 to $5 \mathrm{ft} \ldots \ldots \ldots \ldots \ldots \ldots \ldots .6 \%$

" macrostachya, Dwarf Horse Chestnut

3 to $4 \mathrm{ft} \ldots \ldots \ldots \ldots \ldots \ldots . \ldots 00$

“ rubra, Pink Buck-eye

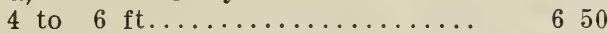

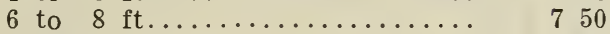

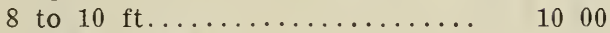

Phellodendron amurense

8 to $10 \mathrm{ft} \ldots \ldots \ldots \ldots \ldots \ldots \ldots . \ldots \ldots$

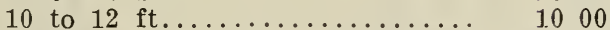

Platanus orientalis, European Sycamore, European Plane

4 to $6 \mathrm{ft} \ldots \ldots \ldots \ldots \ldots \ldots \ldots \ldots . \ldots 200 \quad 1800$

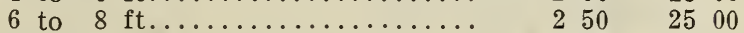

8 to $10 \mathrm{ft} \ldots \ldots \ldots \ldots \ldots \ldots \ldots \ldots .350 .3500$

$11 / 4$ to $1 \frac{1 / 2}{2}$ in. cal............ $750 \quad 6000$

$1 \frac{1}{2}$ to $13 / 4$ in. cal............... $1000 \quad 100 \quad 00$

$13 / 4$ to 2 in. cal........... $1250 \quad 12500$

Populus Bolleana, Pyramidal Silver Poplar

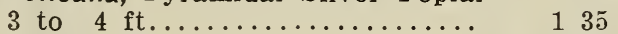

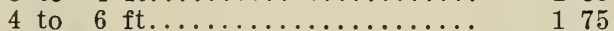

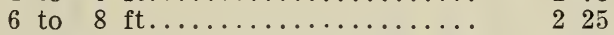

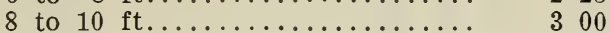

$11 / 4$ to $11 / 2$ in. cal.............. 375

$11 / 2$ to $13 / 4$ in. cal............ 600

$13 / 4$ to 2 in. cal............... 750

2 to $21 / 4$ in. cal.............. 1250

$21 / 4$ to $21 / 2$ in. cal............ 1350

$21 / 2$ to $23 / 4$ in. cal............ 1500

$23 / 4$ to 3 in. cal............. 2000

3 to $31 / 2$ in. cal............. 2750

$3 \frac{1}{2}$ to 4 in. cal........... 3000

“ fastigiata, Lombardy Poplar

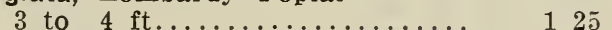

4 to $6 \mathrm{ft} \ldots \ldots \ldots \ldots \ldots \ldots \ldots . \ldots \ldots$

6 to $8 \mathrm{ft} . \ldots \ldots \ldots \ldots \ldots \ldots \ldots \ldots . \ldots \ldots$

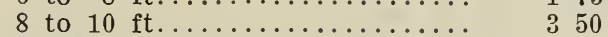

1500

2000

2500

3500

5000

6000

10000

" monilifera, Carolina

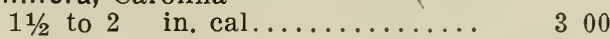

2 to $2 \frac{1}{2}$ in. cal............... 450

Prunus Pissardi (see Shrubs)

Quercus aquatica, Water Oak

6 to $8 \mathrm{ft} \ldots \ldots \ldots \ldots \ldots \ldots \ldots \ldots$

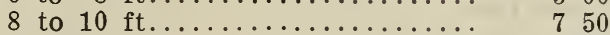

$1 \frac{1 / 4}{4}$ to $1 \frac{1 / 2}{2}$ in. cal............ 1000

$11 / 2$ to 2 in. cal............. 12 . 50

1000

1200

1500

$\begin{array}{ll}30 & 00\end{array}$ 
" bicolor, Swamp White Oak

Per 10 Per 100

4 to $6 \mathrm{ft} . \ldots \ldots \ldots \ldots \ldots \ldots \ldots$

$3 \quad 50 \quad 3500$

6 to $8 \mathrm{ft} . \ldots \ldots \ldots \ldots \ldots \ldots \ldots .6 \%$ 7 $50 \quad 7500$

3 to 4 in. cal. specimens....... 3000

" cerris, Turkey Oak

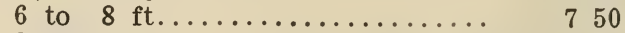

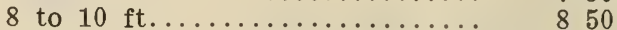

" coccinea, Scarlet Oak

4 to $6 \mathrm{ft} . \ldots \ldots \ldots \ldots \ldots \ldots$

350

6 to $8 \mathrm{ft} . \ldots \ldots \ldots \ldots \ldots \ldots$

750

8 to $10 \mathrm{ft} . \ldots \ldots \ldots \ldots \ldots \ldots . . . .$.

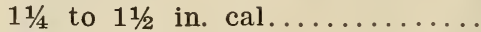

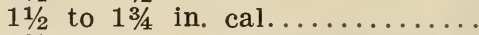

$13 / 4$ to 2

in. cal...............

2 to $2 \frac{1}{4}$ in. cal...........

“ falcata, Spanish Oak

4 to $6 \mathrm{ft} . \ldots \ldots \ldots \ldots \ldots \ldots$

6 to $8 \mathrm{ft} . \ldots . \ldots . . . . . . . . .$.

" imbricaria, Shingle Oak

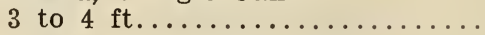

850

1000

1350

1500

1750

350

500

500

“ laurifolia, Laurel-leaved Oak

4 to $6 \mathrm{ft} \ldots \ldots \ldots \ldots \ldots \ldots \ldots \ldots$

" macrocarpa, Mossy Cup or Burr Oak 4 to $6 \mathrm{ft} . \ldots \ldots \ldots \ldots \ldots \ldots$

6 to $8 \mathrm{ft} \ldots \ldots \ldots \ldots \ldots \ldots \ldots \ldots$

8 to $10 \mathrm{ft} . \ldots \ldots \ldots \ldots \ldots \ldots \ldots$

$11 / 4$ to $11 / 2$ in. cal..............

$11 / 2$ to $13 / 4$ in. cal............

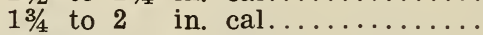

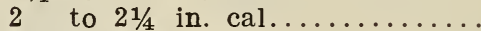

" obtusiloba, Post Oak

4 to $6 \mathrm{ft} . \ldots \ldots \ldots \ldots \ldots \ldots \ldots$

6 to $8 \mathrm{ft} . \ldots \ldots \ldots \ldots \ldots \ldots \ldots \ldots \ldots$

8 to $10 \mathrm{ft} . \ldots \ldots \ldots \ldots \ldots \ldots \ldots$

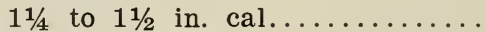

“ palustris, Pin Oak

6 to $8 \mathrm{ft} . \ldots \ldots \ldots \ldots \ldots \ldots \ldots$

8 to $10 \mathrm{ft} . \ldots \ldots \ldots \ldots \ldots \ldots$.

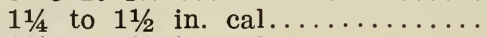

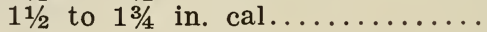

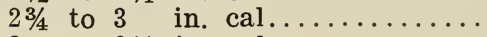

3 to $31 / 2$ in. cal............

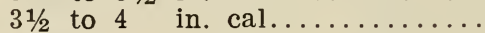

4 to 5

in. cal................

" Prinus, Rock Chestnut Oak

\begin{tabular}{|c|c|c|c|c|}
\hline & & & & \\
\hline to & $6 \mathrm{ft} . \ldots \ldots \ldots \ldots$ & & 50 & \\
\hline 6 to & $8 \mathrm{ft} . \ldots \ldots \ldots \ldots$ & & & \\
\hline 8 to 1 & $10 \mathrm{ft} . .$. & 8 & 50 & \\
\hline $11 / 4$ to & $11 / 2$ in. cal................. & 10 & 00 & $100 \quad 00$ \\
\hline $11 / 2$ to & $13 / 4$ in cal $\ldots \ldots \ldots \ldots \ldots$ & 12 & 50 & 12500 \\
\hline $13 / 4$ to & 2 in. cal. $\ldots \ldots \ldots \ldots \ldots$ & 13 & 50 & 13500 \\
\hline 2 to & $21 / 4$ in cal............. & 15 & 00 & $150 \quad 00$ \\
\hline $21 / 4$ to & $21 / 2$ in. cal.................. & 16 & 50 & 16500 \\
\hline $21 / 2$ to & $23 / 4$ in. cal $\ldots \ldots \ldots \ldots \ldots$ & 17 & 50 & 17500 \\
\hline $23 / 4$ to & 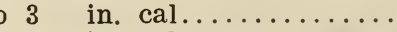 & 25 & 00 & \\
\hline 3 to & 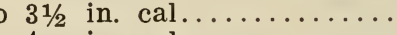 & 30 & 00 & \\
\hline $1 / 2$ to & 4 in. cal............ & 35 & & \\
\hline conc & Golden Oak & & & \\
\hline to 4 & $4 \mathrm{ft} . \ldots$. & & 50 & \\
\hline to 6 & $6 \mathrm{ft}$ & 10 & 00 & \\
\hline & & & & \\
\hline $1 / 2$ to & $23 / 4$ in. cal... & 22 & & \\
\hline to & 3 in. cal. . & 25 & & \\
\hline to & $31 / 2$ in. cal. & 27 & & \\
\hline & al. & 35 & 00 & \\
\hline
\end{tabular}

3500

$\begin{array}{lllll}5 & 00 & 40 & 00\end{array}$

750

1000

$\begin{array}{llll}750 & 75 & 00\end{array}$

$\begin{array}{llll}8 & 50 & 80 & 00\end{array}$

$\begin{array}{llll}9 & 00 & 85 & 00\end{array}$

$\begin{array}{llll}10 & 00 & 100 & 00\end{array}$

2500

2750

3000

4000

$\begin{array}{rr}75 & 00 \\ 85 & 00\end{array}$

10000

12500

4 to $6 \mathrm{ft} . \ldots \ldots \ldots \ldots \ldots \ldots \ldots \ldots$

350

650

850

1000

1250

1350

1500

1650

1750

2500

3000

3500

- robur concordia, Golden Oak

3 to $4 \mathrm{ft} . \ldots \ldots \ldots \ldots \ldots \ldots \ldots$

$31 / 2$ to 4 in. cal............. 3500 
Per 100

- Texana

6 to $8 \mathrm{ft} \ldots \ldots \ldots \ldots \ldots \ldots \ldots \ldots \ldots$

8 to $10 \mathrm{ft} \ldots \ldots \ldots \ldots . \ldots . \ldots . \ldots$

" tinctoria, Black Oak

6 to $8 \mathrm{ft} \ldots \ldots \ldots \ldots \ldots \ldots \ldots \ldots \ldots$

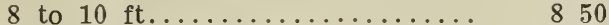

$11 / 4$ to $11 / 2$ in. cal............. 1000

$11 \frac{1}{2}$ to $13 / 4$ in. cal......................... 1250

$13 / 4$ to 2 in. cal............ 1500

2 to $21 / 2$ in. cal............ 1750

$21 / 2$ to 3 in. cal........... 2500

3 to $3 \frac{1}{2}$ in. cal............ 2750

$31 / 2$ to 4 in. cal........... 3000

4 to 5 in. cal............ 4000

12500

17500

25000

Salisburia adiantifolia, Ginkgo or Maiden Hair

6 to $8 \mathrm{ft} . \ldots \ldots \ldots \ldots \ldots \ldots \ldots . \ldots \ldots$

2 to $2 \frac{1}{2}$ in. cal............. 2000

Salix alba, White Willow

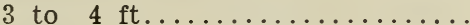
125
4 to $6 \mathrm{ft} . \ldots \ldots \ldots \ldots \ldots \ldots \ldots$
175
6 to $8 \mathrm{ft} \ldots \ldots \ldots \ldots \ldots \ldots \ldots \ldots . \ldots . \ldots . \ldots 250$

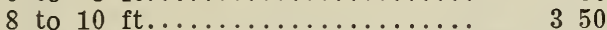
1000
1500
2000
$30 \quad 00$
" aurea pendula, Golden-barked Weeping Willow

4 to $6 \mathrm{ft} . \ldots \ldots \ldots \ldots \ldots \ldots \ldots . \ldots \ldots$

6 to $8 \mathrm{ft} . \ldots \ldots \ldots \ldots \ldots \ldots \ldots \ldots$

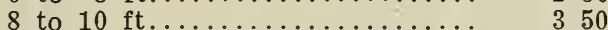

10 to $12 \mathrm{ft} . \ldots \ldots \ldots \ldots \ldots \ldots \ldots . \ldots . \ldots . \ldots$

1500

2000

$30 \quad 00$

$50 \quad 00$

" Babylonica, Weeping Willow

6 to $8 \mathrm{ft} . \ldots \ldots \ldots \ldots \ldots \ldots \ldots$

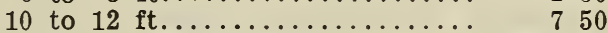

12 to $14 \mathrm{ft} . \ldots \ldots \ldots \ldots \ldots \ldots . \ldots . \ldots . \ldots 1000$

“ regalis, Royal or White-leaved

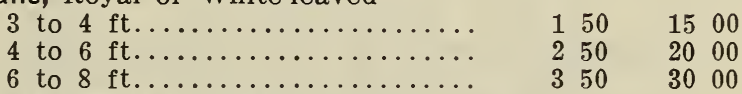

“ Rosmarinifolia, Rosmary Willow

3 to $4 \mathrm{ft} \ldots \ldots \ldots \ldots \ldots \ldots \ldots \ldots \ldots \ldots$ 1 $50 \quad 1500$

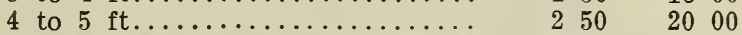

“ vitellina aurea, Golden Bark

\begin{tabular}{|c|c|c|c|}
\hline to & 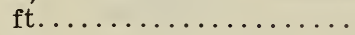 & 125 & 1000 \\
\hline to & ft... & 150 & 15 \\
\hline to & ft. $\ldots \ldots \ldots \ldots \ldots \ldots \ldots$ & 250 & 20 \\
\hline to 10 & $\mathrm{ft} \ldots \ldots \ldots \ldots \ldots \ldots$ & 350 & 30 \\
\hline 012 & . & 500 & 40 \\
\hline
\end{tabular}

“ vitellina Britzensis, Red-barked Willow

4 to $6 \mathrm{ft} . \ldots \ldots \ldots \ldots \ldots \ldots \ldots \ldots$

$\begin{array}{llll}1 & 75 & 15 & 00\end{array}$

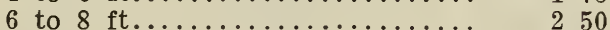

2000

8 to $10 \mathrm{ft} . \ldots \ldots \ldots \ldots \ldots \ldots . \ldots . \ldots . . .300$

"Wisconsin, Weeping

8 to $10 \mathrm{ft} . \ldots \ldots \ldots \ldots \ldots . \ldots \ldots$

Sophora Japonica

3 to $4 \mathrm{ft} . \ldots \ldots \ldots \ldots \ldots \ldots \ldots . \ldots \ldots$

4 to $6 \mathrm{ft} \ldots \ldots \ldots \ldots \ldots \ldots \ldots \ldots \ldots$

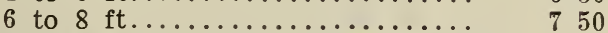

5000

Sorbus aucuparia, European Mountain Ash

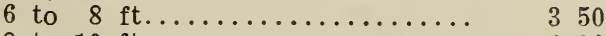

8 to $10 \mathrm{ft} \ldots \ldots \ldots \ldots \ldots \ldots \ldots \ldots \ldots . .6 \%$ 4 400

"Americana, Am. Mt. Ash

$10 \mathrm{ft} ., 11 / 2$ to 2 in. cal.......... 1000

Taxodium distichum, Bald Cypress

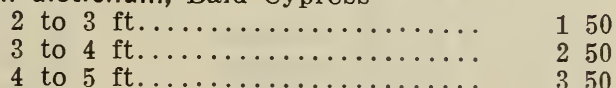




\section{Tilia Americana-American Linden}

The American Linden is one of our best native trees for Avenue or Boulevard planting. It is of rapid growth, attaining large proportions, but with regular symmetrical top. It has good foliage, and the small flowers are very fragrant. It is hardy in all sections of the United States.

We have a very fine stock of these trees, several times transplanted, with perfectly straight trunks. In the sizes from $2 \frac{1}{4} \mathrm{inch}$ and up our trees are regular specimens. The trunks are absolutely straight, with full symmetrical shaped heads, branching from 6 to 7 feet from the ground. So uniform is this lot of trees that they have the appearance of all having been made from one pattern. They are an exceptionally fine lot and the prices of then1 are very low if the quality of the stock is considered. The illustration on the front page of cover, while not being taken from one of our trees, is so near like them as to convey an accurate description of the trees we offer.

Tilia Americana, American Linden

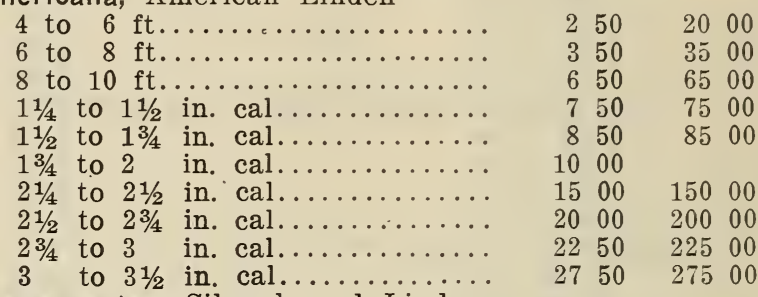

" alba argentea, Silver-leaved Linden
8 to $10 \mathrm{ft}$
750
$21 / 2$ to 3
in. cal.............
7500

2500

3 to 4 in. cal........... 3500

“ dasystyla, Crymean or Yellow-twigged Linden
$13 / 4$ to 2
in. cal..............
1500
2 to $2 \frac{1}{4}$
$21 / 4$ to $21 / 2$
in. cal..............
1750
$21 / 2$ to 3
in. cal..............
2000
2500

"Europaea, European Linden
8 to $10 \mathrm{ft} .1$ to $1 \frac{1 / 2}{\mathrm{in}}$. cal ......
750
$21 / 4$ to $21 / 2$ in. cal............. 1750
$2 \frac{1}{2}$ to $23 / 4$ in. cal............... 2500
$23 / 4$ to 3 in. cal............ 2750
3 to $3 \frac{1}{2}$ in. cal............ 3500

“ plataphylla, Large-leaved European Linden

4 to $6 \mathrm{ft} . \ldots \ldots \ldots \ldots \ldots \ldots . \ldots . \ldots$

\section{UImus Americana, American Elm}

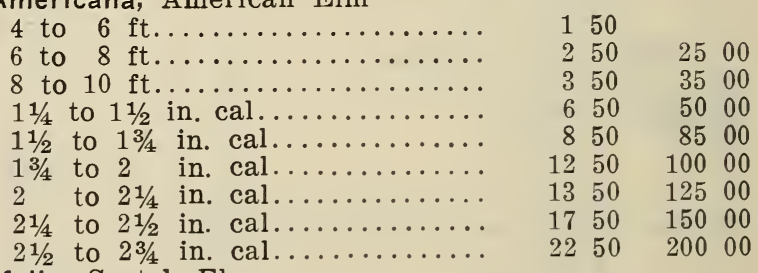

" latifolia, Scotch Elm

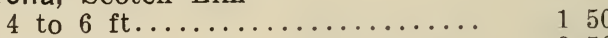

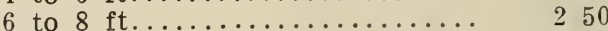

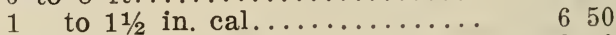

$11 / 2$ to 2 in. cal............ 850

3 to $3 \frac{1}{2}$ in. cal. specimen..... 4000

$31 / 2$ to 4 in. cal. specimen..... 4500

4 to 5 in. cal. specimen..... 5000 
-. racemosa, Cork-barked Elm

Per 10 Per 100

4 to $5 \mathrm{ft} . \ldots \ldots \ldots \ldots \ldots \ldots \ldots \ldots$......... $300 \quad 2500$

“ Campestris, English Elm

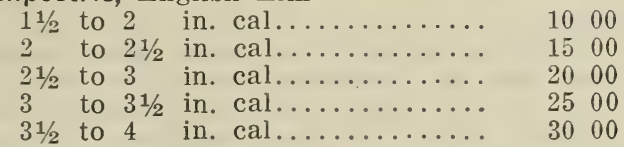

. parvifolia, Japanese Elm

6 to $8 \mathrm{ft} \ldots \ldots \ldots \ldots \ldots \ldots \ldots \ldots$

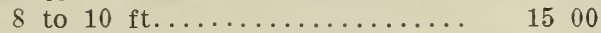

10 to $12 \mathrm{ft} \ldots \ldots \ldots \ldots \ldots \ldots \ldots \ldots$

\section{Specimen Shade Trees}

This is a particularly fine lot of Specimen Shade Trees for planting for immediate results. These trees were transplanted four years ago and set ten by ten feet apart in nursery rows, allowing ample room for top development. They are abundantly supplied with fibrous roots, have good straight trunks and well developed, symmetrical tops. They are mostly branched from six to eight feet from the ground.

When ordering from this list be careful to mention these "specimen trees."

On account of the height of these trees only orders for carload lots can be taken. They cannot be baled and shipped in less than carload lots.

Acer dasycarpum, Silver Maple

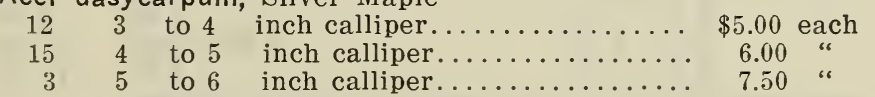

Acer negundo, Box Elder

14 to 5 inch calliper............

25 to 6 inch calliper....................

Acer platanoides, Norway Maple

$6 \quad 3 \frac{1}{2}$ to 4 inch calliper............

34 to 5 inch calliper..................

Acer saccharum, Sugar or Rock Maple

672 to $21 / 2$ inch calliper............ 5.00 "

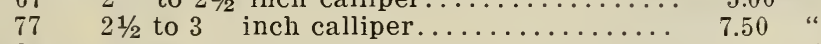

$28 \quad 3$ to $31 / 2$ inch calliper.....................

Catalpa speciosa, Western Catalpa

$34 \quad 3$ to $3 \frac{1}{2}$ inch calliper............. 5.00 "

$45 \quad 31 / 2$ to 4 inch calliper.............

$16 \quad 4^{2}$ to 5 inch calliper...............

Fraxinus Americana, White Ash

$7 \quad 23 / 4$ to 3 inch calliper............ 5.00 .

$10 \quad 3$ to $31 / 2$ inch calliper.......................

Platanus Orientalis, Oriental Plane

$14 \quad 23 / 4$ to 3 inch calliper...........

$45 \quad 3$ to $31 / 2$ inch calliper........................ 12.50 "

Ulmus Americana, American Elm

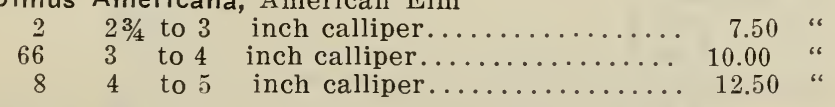




\section{Deciduous Shrubs}

We continually try to impress upon our customers the fact that the mere height of a shrub does not indicate its value, but that its "bushiness" must also be taken into consideration. Shrubs grown closely in nursery rows must necessarily make height, but the "bushiness" is sacrificed. A good, bushy, two to three-feet shrub is worth as much as a "slim" three to four-feet plant, and for results it is worth more.

We grow our shrubs in wide rows and allow plenty of space between the plants in the rows to permit them to develop properly. It costs more to grow shrubs this way than where they are grown closely together, as we cannot plant as many on an acre. In comparing our prices with those of other growers, this fact should be given consideration.

Althaea (see Hibiscus)

Per 10 Per 100

Amelanchier canadensis, Juneberry

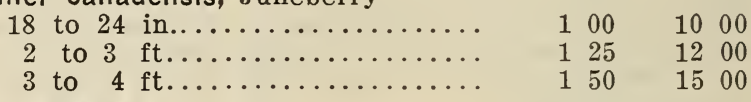

Amorpha canescens

12 to 18 in .................. $100 \quad 1000$

18 to 24 in ................ $125 \quad 1200$

“fruticosa

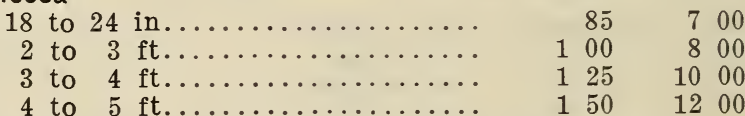

Amygdalus nana, Double White Flowering Almond

2 to $3 \mathrm{ft} . \ldots \ldots \ldots \ldots \ldots \ldots \ldots \ldots \ldots$

“ nana, Double Pink Flowering Almond

2 to $3 \mathrm{ft} . \ldots \ldots \ldots \ldots \ldots \ldots \ldots \ldots \ldots$

“ Persica (see Prunus Persica)

Andromeda arborea (see Oxydendron, trees)

Andromeda floribunda and Japonica (see Evergreen Shrubs)

Aralia Japonica

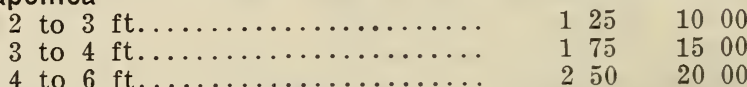

"Mandschurica (Dimorphanthus)

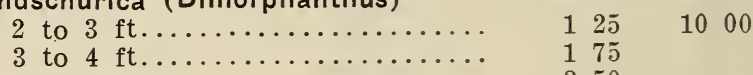

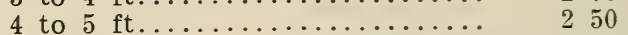

" pentaphylla

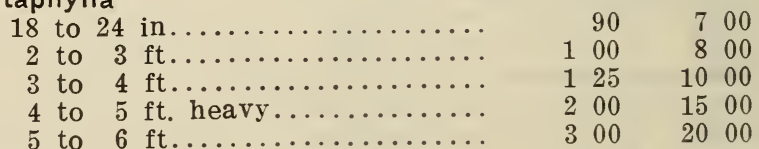

“ spinosa

3 to $4 \mathrm{ft} . \ldots \ldots \ldots \ldots \ldots \ldots \ldots \ldots \ldots \ldots \ldots \ldots \ldots \ldots \ldots \ldots \ldots$
6 to $8 \mathrm{ft} . \ldots \ldots \ldots \ldots \ldots \ldots$

Aronia melanocarpa, Black Choke-berry

18 to 24 in................... 85

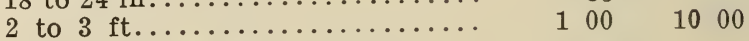

Azalea lutea (calendulacea)

18 to 24 in................ $350 \quad 3000$ 
“Vaseyii

Per 10 Per 100

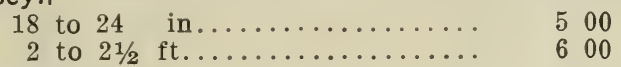

“ Mollis, Red

$$
18 \text { to } 24 \text { in.............. } 500
$$

- Mollis, Yellow

18 to 24 in................ 500

"Pontica (Ghent), Assorted Varieties

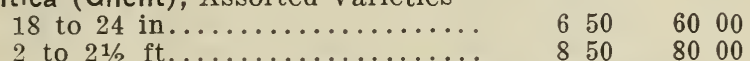

Daviesii, White, Very Fine, Single

\section{LIST OF VARIETIES}

Geant des Batailles, Dark Carmine, Single

Nancy Waterer, Pure Yellow, Single

Narcissiflora, Sulphur Yellow, Double

Pucella, Bright Red, Single

Raphael de Smet, White Shaded with Rose, Double

Berberis purpurea, Purple Barberry

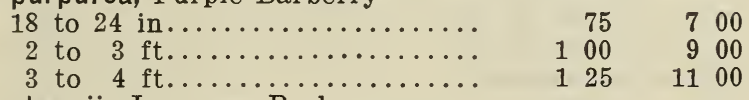

. Thunbergii, Japanese Barberry

$\begin{array}{llllrrr}12 & \text { to } 18 \text { in. } \$ 65.00 \text { per } 1000 \ldots & & 85 & 7 & 00 \\ 18 & \text { to } 24 & \text { in. } 100.00 \text { per } 1000 \ldots & 1 & 25 & 10 & 00 \\ 2 & \text { to } 21 / 2 & \text { ft. } 140.00 \text { per } 1000 \ldots & 1 & 50 & 15 & 00 \\ 21 / 2 & \text { to } 3 & \text { ft. extra heavy....... } & 2 & 00 & 20 & 00 \\ 3 & \text { to } 4 & \text { ft heavy............ } & 2 & 50 & 25 & 00\end{array}$

" vulgaris, Green Barberry

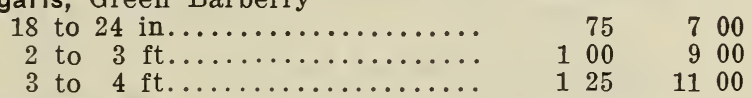

Buddleia intermedia

2 to $3 \mathrm{ft} . \ldots \ldots \ldots \ldots \ldots \ldots \ldots \ldots \ldots \ldots \ldots \ldots \ldots$
3 to $4 \mathrm{ft} . \ldots \ldots \ldots \ldots \ldots \ldots$

Callicarpa purpurea

3 to $4 \mathrm{ft} . \ldots \ldots \ldots \ldots \ldots \ldots \ldots$. $150 \quad 1400$

Calycanthus floridus, Sweet Shrub

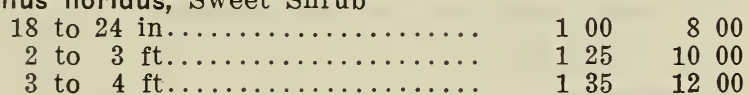

Caragana arborescens, Siberian Pea

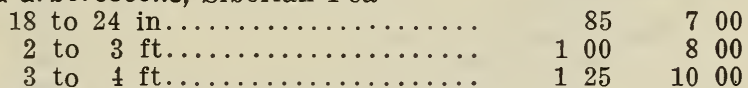

“ arborescens pendula, Weeping Siberian Pea

4 to $6 \mathrm{ft}$. stems, 4 year heads.... 1000

6 to $8 \mathrm{ft}$. stems, 4 year heads.... 1250

Carpinus Americana, American Hornbeam
2 to $3 \mathrm{ft} . \ldots \ldots \ldots \ldots \ldots \ldots \ldots$

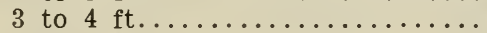
4 to $5 \mathrm{ft} . \ldots \ldots \ldots \ldots \ldots \ldots \ldots \ldots$
5 to $6 \mathrm{ft} \ldots \ldots \ldots \ldots \ldots \ldots \ldots \ldots$
6 to $7 \mathrm{ft} . \ldots \ldots \ldots \ldots \ldots \ldots \ldots \ldots$
$\begin{array}{llll}100 & 600\end{array}$
$150 \quad 800$
$200 \quad 1200$
$\begin{array}{llll}2 & 50 & 15 & 00\end{array}$
$\begin{array}{llll}5 & 00 & 35 & 00\end{array}$

" Betulus, European Hornbeam

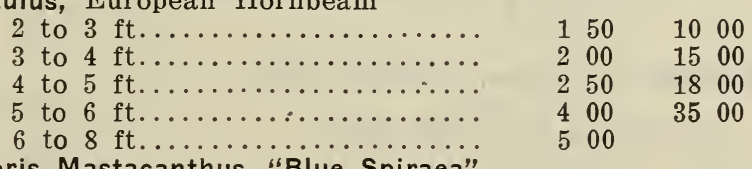

Caryopteris Mastacanthus, "Blue Spiraea"

18 to 24 in................... $125 \quad 1100$

Ceanothus Americanus, New Jersey Tea

18 to 24 in.................. 135 
Cephalanthus occidentalis, Dwarf Button-bush

Per 10 Per 100

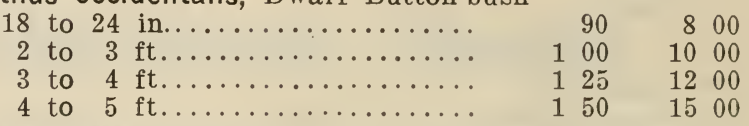

Cercis Canadensis, American Judas or Red Bud

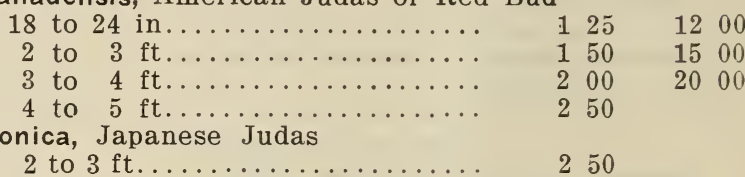

Chionanthus Virginica, White Fringe

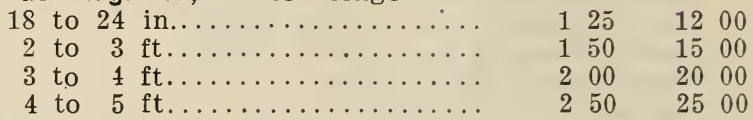

Clethra alnifolia, Sweet Pepper Bush

18 to 24 in................. $125 \quad 1100$

2 to $3 \mathrm{ft} . \ldots \ldots \ldots \ldots \ldots \ldots \ldots .6150$

Colutea arborescens

3 to $4 \mathrm{ft} \ldots \ldots \ldots \ldots \ldots \ldots \ldots \ldots$. $125 \quad 1000$

Corchorus (see Kerria)

Cornus alba (Siberica), Red-twigged Dogwood

2 to $3 \mathrm{ft} \ldots \ldots \ldots \ldots \ldots \ldots \ldots . \ldots 125 \quad 1100$

3 to $4 \mathrm{ft} \ldots \ldots \ldots \ldots \ldots \ldots \ldots . \ldots 135 \quad 1200$

“ alternifolia, Blue Dogwood

2 to $3 \mathrm{ft} . \ldots \ldots \ldots \ldots \ldots \ldots \ldots . \ldots \ldots$

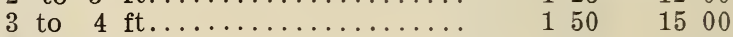

" florida, White Flowered Dogwood

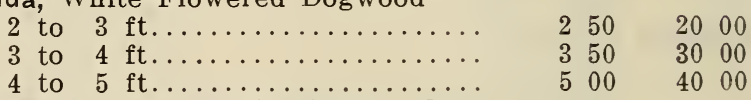

“ florida pendula, Weeping Dogwood

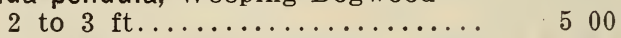

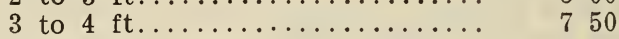

" florida rubra, Red Flowered Dogwood

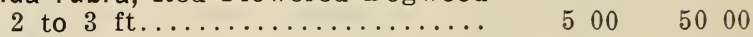

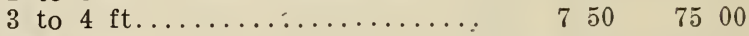

“ glabrata

5 to $6 \mathrm{ft} \ldots \ldots \ldots \ldots \ldots \ldots \ldots$

“ Mas. Cornelian Cherry

18 to 24 in.................... $100 \quad 900$

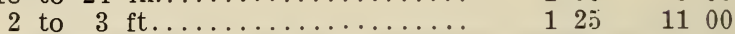

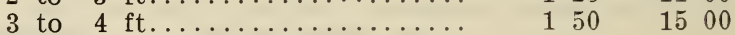

“paniculata

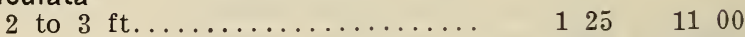

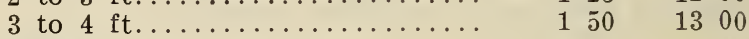

" sanguinea, English Dogwood

2 to $3 \mathrm{ft} \ldots \ldots \ldots \ldots \ldots \ldots \ldots . \ldots . \ldots 100 \quad 10 \ldots$

3 to $4 \mathrm{ft} \ldots \ldots \ldots \ldots \ldots \ldots \ldots . \ldots 125 \quad 1000$

4 to $5 \mathrm{ft} \ldots \ldots \ldots \ldots \ldots \ldots \ldots \ldots$ i $50 \quad 1500$

" sericea (Amomum), Silky Dogwood

5 to $6 \mathrm{ft} \ldots \ldots \ldots \ldots \ldots \ldots \ldots \ldots 20 . \ldots \ldots$

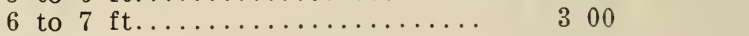

Corylus Americana, American Hazel

2 to $3 \mathrm{ft} . \ldots \ldots \ldots \ldots \ldots \ldots . .150$

" avellena, European Hazel

2 to $3 \mathrm{ft} . \ldots \ldots \ldots \ldots \ldots \ldots \ldots \ldots . \ldots \ldots$

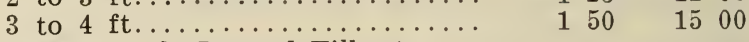

" purpurea, Purple Leaved Filbert

2 to $3 \mathrm{ft} \ldots \ldots \ldots \ldots \ldots \ldots \ldots 200 \quad 2000$ 


\section{Cotoneaster Simondsii}

18 to 24 in................................. $125 \quad 1200$

2 to $3 \mathrm{ft} . \ldots \ldots \ldots \ldots \ldots \ldots \ldots . \ldots \ldots$

Crataegus coccinea, White Thorn

2 to $3 \mathrm{ft} \ldots \ldots \ldots \ldots \ldots \ldots \ldots \ldots \ldots$

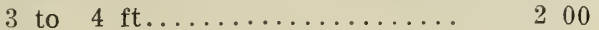

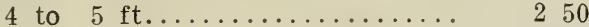

5 to $6 \mathrm{ft} \ldots \ldots \ldots \ldots \ldots \ldots \ldots \ldots . \ldots \ldots$

“ Cordata, Washington Thorn

2 to $3 \mathrm{ft} \ldots \ldots \ldots \ldots \ldots \ldots \ldots \ldots$

3 to $4 \mathrm{ft} . \ldots \ldots \ldots \ldots \ldots \ldots \ldots$

4 to $5 \mathrm{ft} \ldots \ldots \ldots \ldots \ldots \ldots \ldots \ldots$

5 to $6 \mathrm{ft} \ldots \ldots \ldots \ldots \ldots \ldots \ldots \ldots$

6 to $8 \mathrm{ft} \ldots \ldots \ldots \ldots \ldots \ldots \ldots$

crus galli, Cockspur Thorn

3 to $4 \mathrm{ft} \ldots \ldots \ldots \ldots \ldots \ldots \ldots . \ldots 250$

" mollis

2 to $3 \mathrm{ft} . \ldots \ldots \ldots \ldots \ldots \ldots \ldots . \ldots 200$

2000

" oxycantha, English Hawthorn

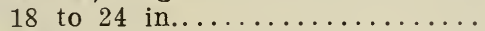

2 to $3 \mathrm{ft} \ldots \ldots \ldots \ldots \ldots \ldots \ldots$

3 to $4 \mathrm{ft}$.

150

250

300

400

500

2000

2500

1500

2500

3000

4000

5000

$1.00 \quad 800$

125

175

“ oxycantha Double Pink

4 to $5 \mathrm{ft} . \ldots \ldots \ldots \ldots \ldots \ldots . \ldots 250$

" oxycantha Paul's Scarlet

4 to $5 \mathrm{ft} \ldots \ldots \ldots \ldots \ldots \ldots \ldots . \ldots 250$

" oxycantha Double White

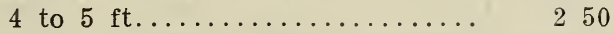

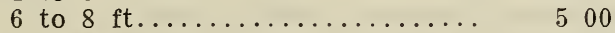

" spathulata

7 to 8 ft.................. 350

Cydonia Japonica (Pyrus Japonica), Japanese Quince

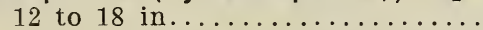

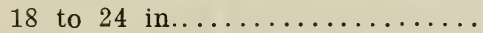

2 to $3 \mathrm{ft} \ldots \ldots \ldots \ldots \ldots \ldots \ldots \ldots$

“ umbillicata, Bright Rose

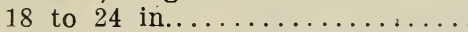

2 to $3 \mathrm{ft} \ldots \ldots \ldots \ldots \ldots \ldots \ldots \ldots$

3 to $4 \mathrm{ft}$

$\mathrm{ft}$

Cytissus Laburnum

4 to $6 \mathrm{ft}$

6 to $8 \mathrm{ft}$

Daphne Mezereum album

18 to 24 in. with ball........

2 to $2 \frac{1}{2} \mathrm{ft}$. with bali.

“ Mezereum rubrum, Pink

2 to $2 \frac{1}{2} \mathrm{ft}$. with ball....... 750

Desmodium penduliflorum, Pink

3 year

75

100

125

600

800

1000

$\begin{array}{llll}1 & 00 & 9 & 00\end{array}$

$125 \quad 1100$

$150 \quad 1200$

$200 \quad 2000$

$350 \quad 3000$

$500 \quad 50 \quad 00$

$650 \quad 6500$

$125 \quad 1000$

Deutzia candidissima plena, Double White

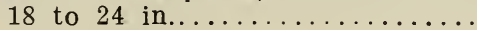

2 to $3 \mathrm{ft} \ldots \ldots \ldots \ldots \ldots \ldots \ldots$

3 to $4 \mathrm{ft}$

t.....................

“ crenata, Double Pink

18 to 24 in................. 90

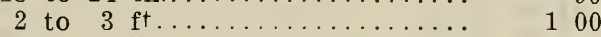

3 to $4 \mathrm{ft} \ldots \ldots \ldots \ldots \ldots \ldots \ldots \ldots$

$90 \quad 800$
180

$100 \quad 900$

$125 \quad 1000$

$125 \quad 1000$

“ Fortuneii, White

2 to $3 \mathrm{ft} \ldots \ldots \ldots \ldots \ldots \ldots \ldots \ldots$

3 to $4 \mathrm{ft} \ldots \ldots \ldots \ldots \ldots \ldots \ldots \ldots \ldots \ldots$

$125 \quad 1000$ 
“ gracilis, Dwarf White

Per 10 Per 100

12 to 18 in................ $85 \quad 700$

18 to 24 in................. $100 \quad 1000$

2 to $2 \frac{1}{2} \mathrm{ft} \ldots \ldots \ldots \ldots \ldots \ldots \ldots \ldots . .6125 \quad 1100$

- gracilis rosea, Pink

18 to 24 in............... 100

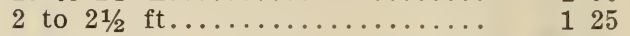

1000

“ Lemoinei, Dwarf White

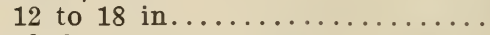

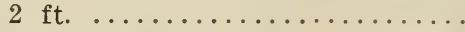

85700

$125 \quad 1100$

“ Pride of Rochester, Double Pink

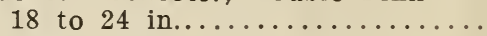

2 to $3 \mathrm{ft} . \ldots \ldots \ldots \ldots \ldots \ldots \ldots$

3 to $4 \mathrm{ft} . \ldots \ldots \ldots \ldots \ldots \ldots . . . .$.

$\begin{array}{lll}90 & 8 & 00\end{array}$

$100 \quad 900$

$125 \quad 1000$

Diervilla sessilifolia (lutea)

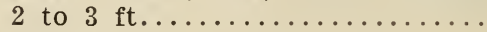

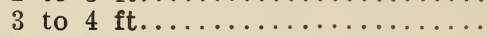

$\begin{array}{llll}125 & 1200\end{array}$

$150 \quad 1500$

Dimorphanthus (see Aralia Mandschurica)

Eleagnus angustifolia, Russian Olive

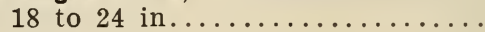

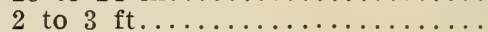

3 to $4 \mathrm{ft} . \ldots \ldots \ldots \ldots \ldots \ldots \ldots \ldots \ldots$

- longipes

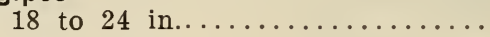

2 to $3 \mathrm{ft} . \ldots \ldots \ldots \ldots \ldots \ldots$

Euonymus alatus, Japanese Euonymus

2 to $3 \mathrm{ft} . \ldots \ldots \ldots \ldots \ldots \ldots$

3 to $4 \mathrm{ft} . . . \ldots \ldots \ldots \ldots \ldots . . . .$.

$100 \quad 800$

$\begin{array}{llll}125 & 10 & 00\end{array}$

$135 \quad 1200$

$100 \quad 1000$

$\begin{array}{llll}1 & 25 & 11 & 00\end{array}$

$250 \quad 2500$

$350 \quad 3000$

“ Americana, American Burning Bush

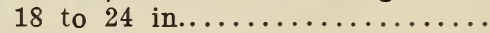

2 to $3 \mathrm{ft} . . . \ldots \ldots \ldots \ldots \ldots . . . . . .$.

$\begin{array}{llll}1 & 00 & 10 & 00\end{array}$

$150 \quad 1500$

" atropurpureus, Strawberry Tree

3 to $3 \frac{1 / 2}{\mathrm{ft}} . \ldots \ldots \ldots \ldots \ldots \ldots \ldots \ldots$

- Europaeus, European Burning Bush

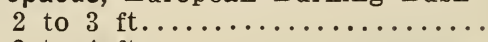

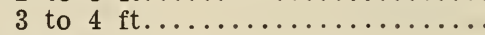

Exochorda grandiflora,.Pearl Bush

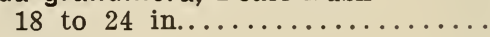

2 to $3 \mathrm{ft} . \ldots \ldots \ldots \ldots \ldots \ldots \ldots$

3 to $4 \mathrm{ft} . \ldots \ldots \ldots \ldots \ldots \ldots \ldots$

4 to $5 \mathrm{ft} . \ldots \ldots \ldots \ldots \ldots \ldots . . . .$.

$150 \quad 1500$

$\begin{array}{llll}1 & 00 & 10 & 00\end{array}$

$125 \quad 1200$

$\begin{array}{llll}1 & 00 & 10 & 00\end{array}$

$125 \quad 1200$

$\begin{array}{llll}150 & 15 & 00\end{array}$

$\begin{array}{llll}185 & 18 & 00\end{array}$

Forsythea Fortunei, Golden Bell

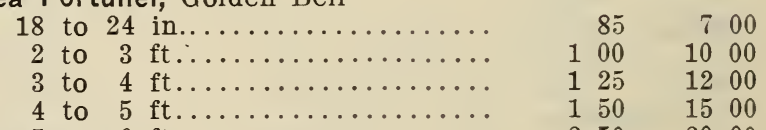

“ intermedia

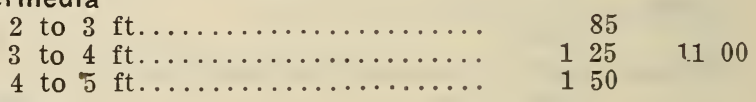

“ suspensa

18 to 24 in............... $100 \quad 900$

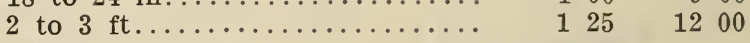

“ viridissima

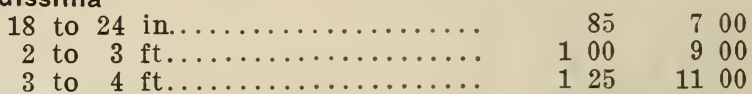

4. viridissima variegata

3 to $4 \mathrm{ft} \ldots \ldots \ldots \ldots \ldots \ldots \ldots . \ldots \ldots$ 
Halesia tetraptera, Silver Bell

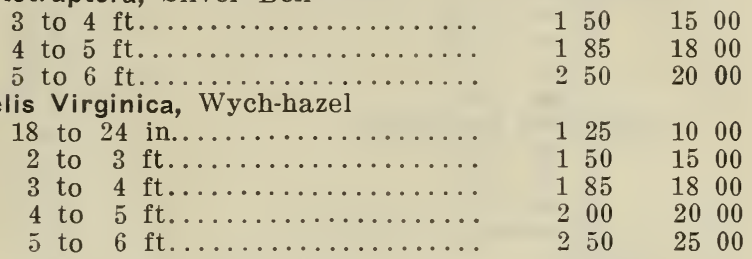

Hibiscus alba plena, Double White Althaea

2 to $3 \mathrm{ft} . \ldots \ldots \ldots \ldots \ldots \ldots$.

4 to $5 \mathrm{ft} . \ldots \ldots \ldots \ldots \ldots \ldots$

“ ardens, Double Blue

2 to $3 \mathrm{ft} \ldots \ldots \ldots \ldots \ldots \ldots \ldots$.

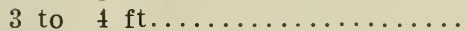

" bicolor, Double Pink

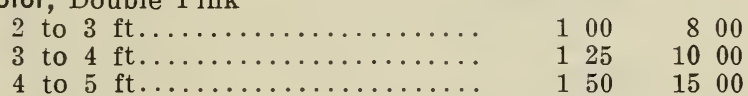

- Boule de Feu

2 to $3 \mathrm{ft} . \ldots \ldots \ldots \ldots \ldots \ldots . \ldots \ldots$

- carnea plena, Double Red

18 to 24 in................. 85

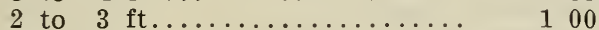

3 to $4 \mathrm{ft} . \ldots \ldots \ldots \ldots \ldots \ldots . \ldots . \ldots . \ldots 25$

- Duc de Brabant

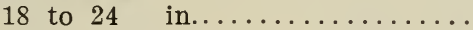

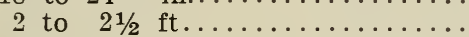

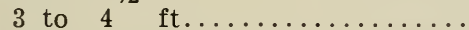

- Jean d'Arc, Double White

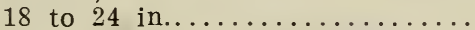

2 to $3 \mathrm{ft} . \ldots \ldots \ldots \ldots \ldots \ldots \ldots \ldots$

3 to $4 \mathrm{ft} . \ldots \ldots \ldots \ldots \ldots \ldots \ldots$

- Lady Stanley, Double Pink

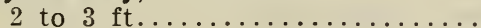

3 to $4 \mathrm{ft} . \ldots \ldots \ldots \ldots \ldots \ldots \ldots . \ldots \ldots$

. variegata fl. pl., Variegated-leaved, Double Red

18 to 24 in 85

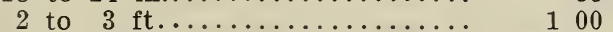

3 to $4 \mathrm{ft} . \ldots \ldots \ldots \ldots \ldots \ldots . . .625$

4 to $5 \mathrm{ft} . \ldots \ldots \ldots \ldots \ldots \ldots . \ldots . \ldots 150$

Coelestis, Single Blue
18 to 24

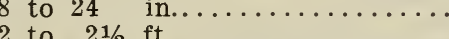
85

100

800

1000

700

800

1000 1500

- Meehani variegated Single Flowered

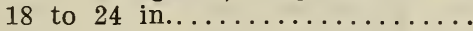
2 to $3 \mathrm{ft} . \ldots \ldots \ldots \ldots \ldots \ldots \ldots \ldots$
3 to $4 \mathrm{ft} . \ldots \ldots \ldots \ldots \ldots \ldots \ldots \ldots \ldots \ldots \ldots \ldots$
4 to $5 \mathrm{ft}$

" rubis, Single Red

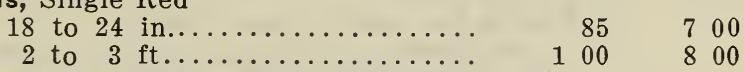

- totus albus, Single Pure White

12 to 18 in................. $85 \quad \begin{array}{lll}7 & 00 \\ 18 & & 85\end{array}$

Hippophaea rhamnoides, Sea Buckthorn

18 to 24 in................. $100 \quad 800$

Hydrangea arborescens grandiflora (new), American Everblooming Hydrangea

2 to $21 / 2 \mathrm{ft} \ldots \ldots \ldots \ldots \ldots \ldots \ldots .200 \quad 200$

“ Hortensia Japonica, Blue Hydrangea

12 to 18 in.................... 175

18 to 24 in..................... 250 
“ paniculata (type), Single

Per 10 Per 100

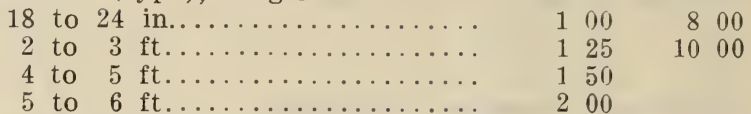

" paniculata grandiflora

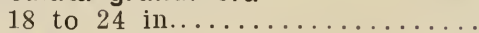

2 to $3 \mathrm{ft} \ldots \ldots \ldots \ldots \ldots \ldots \ldots$

3 to $4 \mathrm{ft} . \ldots \ldots \ldots \ldots \ldots \ldots$

Standards, $21 / 2 \mathrm{ft}$. stems.........

" radiata

2 to $3 \mathrm{ft}$.

Hypericum aureum

18 to 24 in.............. $125 \quad 1100$

"densiflorum

2 to $3 \mathrm{ft} . \ldots \ldots \ldots \ldots \ldots \ldots \ldots \ldots$

“ Moserianum

12 to 18 in................ $125 \quad 1200$

“ patulum

5 in. pots............... $200 \quad 2000$

18 to 24 in................ $125 \quad 1000$

llex verticillata (Prinos)

18 to 24 in................ $200 \quad 2000$

Itea Virginica, New Jersey Tea

18 to 24 in.............. $135 \quad 1300$

Kerria Japonica, Single (Corchorus)

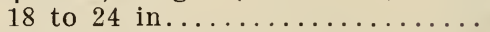

3 to $4 \mathrm{ft} . \ldots \ldots \ldots \ldots \ldots \ldots$

$100 \quad 1000$

$125 \quad 1200$

“ Japonica fl. pl., Double

2 to $3 \mathrm{ft} \ldots \ldots \ldots \ldots \ldots \ldots \ldots \ldots \ldots$

" Japonica varicgita
$2 \mathrm{ft} . . . . . . . .$.
$125 \quad 1200$

Laurus Benzoin (see Lindera)

Lespedeza bicolor

18 to 24 in.................. 125

Ligustrum amurense, Amoor Privet

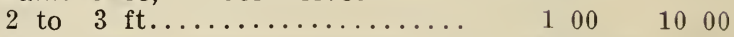

4 to $5 \mathrm{ft} . \ldots \ldots \ldots \ldots \ldots \ldots . . . . .$.

150

“ ibota, as commonly sold, not upright 18 to 24 in., bushy, $\$ 60.00$ per 1000

2 to $3 \mathrm{ft}$., bushy, $\$ 70.00$ per 1000

3 to $4 \mathrm{ft}$., bushy, $\$ 90.00$ per 1000

“ ibota, upright form

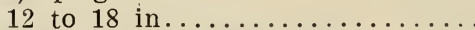

$\begin{array}{lll}85 & 700\end{array}$

$100 \quad 800$

$125 \quad 10 \quad 00$

“ ovalifolium, California Privet

12 to 18 in., $\$ 12.00$ per $1000 \ldots \ldots$

2 to 3 ft., $\$ 25.00$ per $1000 \ldots \ldots$.

3 to $4 \mathrm{ft}$., $\$ 30.00$ per $1000 \ldots \ldots$

12 to 18 in., heavy trans., $\$ 30.00$ per $1000 \ldots \ldots \ldots \ldots \ldots$

18 to 24 in., heavy trans., $\$ 3500$ per $1000 \ldots \ldots \ldots \ldots \ldots$

2 to 3 ft., heavy trans., $\$ 40.00$ per $1000 \ldots \ldots \ldots \ldots \ldots$

3 to $4 \mathrm{ft}$, , heavy trans., $\$ 60.00$ per $1000 \ldots \ldots \ldots \ldots \ldots$.

4 to $5 \mathrm{ft}$., heavy trans.......

“ Regelianum

$\begin{array}{rrrrr} & 75 & & 6 & 00 \\ & & & \\ 25 & & 1 & 35 \\ 50 & & 3 & 00 \\ 75 & & 3 & 50 \\ & & & \\ & 85 & & 4 & 00 \\ 1 & 00 & & 5 & 0 \\ 1 & 25 & & 6 & 00 \\ & & & & \\ 1 & 35 & & 8 & 00 \\ 1 & 50 & & 10 & 00\end{array}$

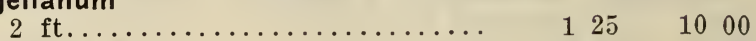

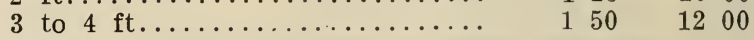

" vulgaris, Common Privet

4 to $5 \mathrm{ft} \ldots \ldots \ldots \ldots \ldots \ldots \ldots \ldots$ 
Lindera Benzoin, Spice Bush

2 to $3 \mathrm{ft} . \ldots \ldots \ldots \ldots \ldots \ldots \ldots \ldots$

3 to $4 \mathrm{ft} \ldots \ldots \ldots \ldots \ldots \ldots \ldots$

Lonicera Alberti

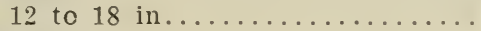

- bella albida

4 to $5 \mathrm{ft} \ldots \ldots \ldots \ldots \ldots \ldots \ldots \ldots \ldots$

-bella candida

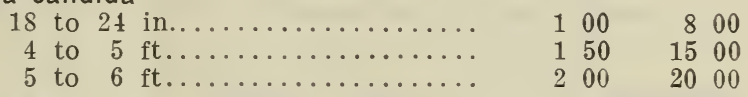

" fragrantissima

2 to $3 \mathrm{ft} \ldots \ldots \ldots \ldots \ldots \ldots . \ldots . \ldots$

3 to 4 ft $\ldots . . . . . . . . . .$.

"Ledebouri

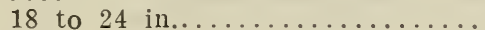

2 to $3 \mathrm{ft} \ldots \ldots \ldots \ldots \ldots \ldots \ldots$

“ Morrowii

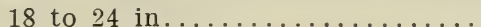
2 to $3 \mathrm{ft} \ldots \ldots \ldots \ldots \ldots \ldots \ldots$
3 to $4 \mathrm{ft}$
3 to $4 \mathrm{ft} . \ldots \ldots \ldots \ldots \ldots \ldots \ldots \ldots$

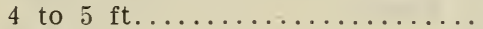

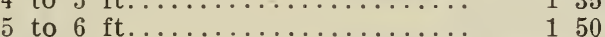

" Orientalis, White

“ Ruprechtiana

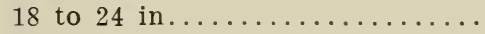

2 to $3 \mathrm{ft} . \ldots \ldots \ldots \ldots \ldots \ldots \ldots \ldots$

3 to $4 \mathrm{ft} \ldots \ldots \ldots \ldots \ldots \ldots \ldots \ldots$

4 to $5 \mathrm{ft} . \ldots \ldots \ldots \ldots \ldots \ldots \ldots$

" Siberica, Siberian Honeysuckle

4 to 5 ft................ 200

"Tatarica alba

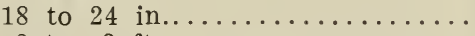

2 to $3 \mathrm{ft} \ldots \ldots \ldots \ldots \ldots \ldots \ldots$

3 to $4 \mathrm{ft} \ldots \ldots \ldots \ldots \ldots \ldots \ldots$

“ Tatarica, Red

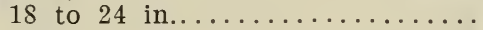

2 to $3 \mathrm{ft} \ldots \ldots \ldots \ldots \ldots \ldots \ldots \ldots$

3 to $4 \mathrm{ft} . \ldots \ldots \ldots \ldots \ldots \ldots \ldots$

"Tatarica grandiflora rosea, Pink

2 to $3 \mathrm{ft} \ldots \ldots \ldots \ldots \ldots \ldots \ldots$

3 to $4 \mathrm{ft} . \ldots \ldots \ldots \ldots \ldots \ldots \ldots$

“ Xylosteum, Fly Honeysuckle
2 to $3 \mathrm{ft}$.

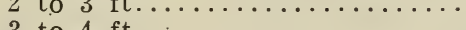

Myrica cerifera, Wax Myrtle

18 to 24 in................ 200

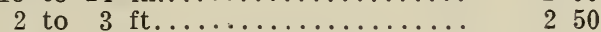

Oxydendron arboreum (see Trees)

Pavia macrostachya, Dwarf Horse Chestnut

3 to $4 \mathrm{ft} . \ldots \ldots \ldots \ldots \ldots \ldots . \ldots \ldots$

Philadelphus aureus

18 to 24 in................ 125

1200

"Avalanche

2 to $21 / 2 \mathrm{ft} . \ldots \ldots \ldots \ldots \ldots \ldots \ldots 135 \quad 1300$

" coronarius, Sweet Flowered Mock Orange

2 to $3 \mathrm{ft} \ldots \ldots \ldots \ldots \ldots \ldots \ldots \ldots \ldots \ldots$

3 to $4 \mathrm{ft} \ldots \ldots \ldots \ldots \ldots \ldots \ldots \ldots \ldots . \ldots \ldots$

1000

1200 
Per 10 Per 100

- grandiflora, Large Flowered Mock Orange

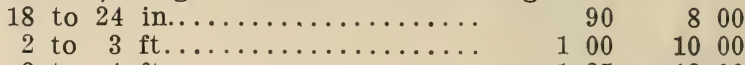

"Lemoinei

3 to $4 \mathrm{ft} . \ldots \ldots \ldots \ldots \ldots \ldots \ldots . . .6125 \quad 1200$

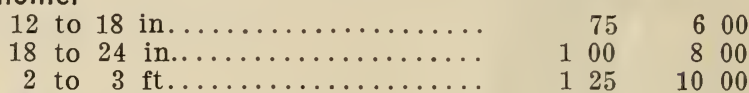

“ nanus, Dwarf Mock Orange

12 to 18 in ........................... $75 \quad 600$

18 to 24 in................... $100 \quad 800$

Potentilla fruticosa, Shrubby Cinquefoil

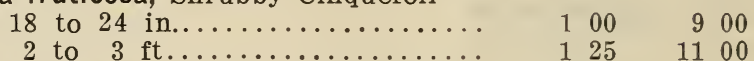

Prinos verticillata (see Ilex verticillata)

Prunus Japonica (see Amygdalus nana)

“Persica, Double Red Flowering Peach

“Persica, Double Pink Flowering Peach

.Persica, Double White Flowering Peach

3 to $4 \mathrm{ft} \ldots \ldots \ldots \ldots \ldots \ldots \ldots \ldots . \ldots 200 \quad 1800$

“Pissardi, Purple-leaved Plum

4 to $5 \mathrm{ft} \ldots \ldots \ldots \ldots \ldots \ldots \ldots \ldots 250 \quad 2200$

“ triloba, Dbl. fl. Plum

3 to $31 / 2$ ft................. $200 \quad 1800$

Ptelea trifoliata, Hop Tree

$200 \quad 1800$

$200 \quad 1800$

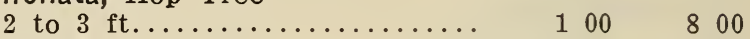

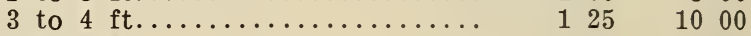

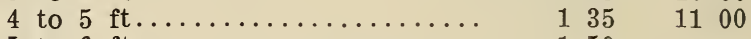

5 to $6 \mathrm{ft} . \ldots \ldots \ldots \ldots \ldots \ldots \ldots$

Pyrus Japonica (see Cydonia Japonica)

" arbutifolia (see Aronia arbutifolia)

“ Bechtel's and other varieties (see Malus. Trees)

Rhamnus frangula

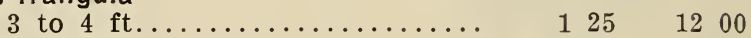

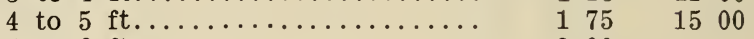

5 to $6 \mathrm{ft} \ldots \ldots \ldots \ldots \ldots \ldots \ldots \ldots .200$.

Rhodotyphus kerroides

18 to 24 in............... $100 \quad 800$

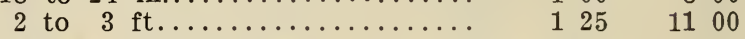

Rhus aromatica, Sweet Sumach

18 to 24 in................................. $200 \quad 2000$

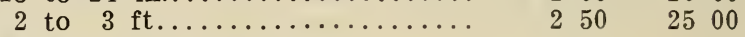

" copallina, Shining Sumach

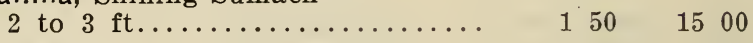

“ cotinus, Mist or Smoke Tree

\begin{tabular}{|c|c|c|c|c|}
\hline 18 to & 24 in.. & & 90 & 800 \\
\hline 2 to & $3 \mathrm{ft} .$. & 1 & & 1000 \\
\hline to & $4 \mathrm{ft}$. & & & 1100 \\
\hline 4 & $5 \mathrm{ft} . \ldots$ & & 50 & 1300 \\
\hline & $6 \mathrm{ft}$. & 2 & 00 & 20 \\
\hline
\end{tabular}

“ glabra, Smooth Sumach

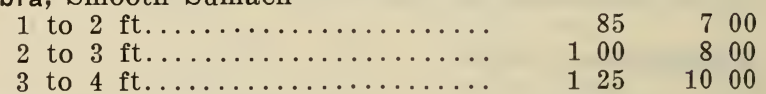

“ Osbecki, Japanese Sumach

18 to 24 in.................... 250

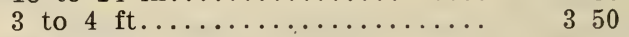

“ typhina, Stag's Horn Sumach

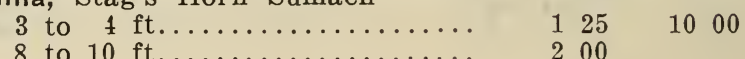


“ typhina laciniata, Cut Leaved

Per 10 Per 100

2 to 3 ft........................

$125 \quad 1100$

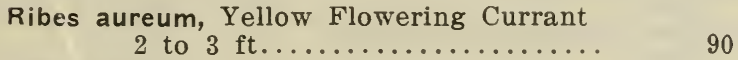

"alpinum

“ carneum

$90 \quad 800$

2 to $3 \mathrm{ft} . \ldots \ldots \ldots \ldots \ldots \ldots \ldots \ldots$

- sanguineum, Crimson Flowering Currant

2 to $3 \mathrm{ft} . \ldots \ldots \ldots \ldots \ldots \ldots . \ldots \ldots$

1500

Robinia hispida rosea, Rose Acacia

2 to $3 \mathrm{ft} \ldots \ldots \ldots \ldots \ldots \ldots \ldots \ldots . \ldots \ldots$

Rosa blanda

18 to 24 in................. $125 \quad 1100$

" humilis

18 to 24 in..................... $125 \quad 1100$

“ lucida

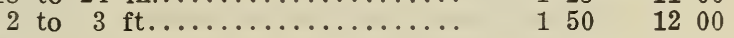

" multiflora Japonica

$125 \quad 1200$

- nitida

18 to 24 in................ $125 \quad 1100$

" rubiginosa, Sweet Brier 18 to 24 .

1251100

18 to 24 in ................ $85 \quad 700$

2 to $3 \mathrm{ft} . \ldots \ldots \ldots \ldots \ldots \ldots \ldots . \ldots \ldots$

- rubrifolia

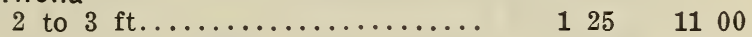

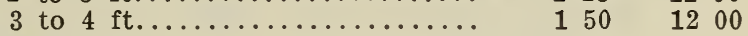

" rugosa, Red

18 to 24 in................ $100 \quad 900$

2 to $3 \mathrm{ft} . \ldots \ldots \ldots \ldots \ldots \ldots \ldots . .125 \quad 1000$

- rugosa, White

18 to 24 in .................. $100 \quad 900$

" Conna to 3 ft.................. $125 \quad 1200$

"Conrad Ferd. Meyer, Double Pink

2 year................... $150 \quad 1500$

“ Mme. Geo. Bruant, Double White

2 year.................. $150 \quad 1500$

“ setigera, Prairie Rose

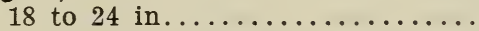

\section{Climbing and Pillar Roses}

\section{Rose Crimson Rambler}

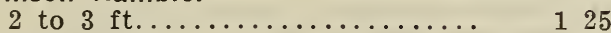

3 to $4 \mathrm{ft} . \ldots \ldots \ldots \ldots \ldots \ldots \ldots \ldots \ldots$

1200

“Mme. Plantier

5 in. pots................. 200

" Pink Rambler

5 in. pots................ 200

"Queen of Prairie, Double Pink

5 in. pots............... 200

- Tausendschon, Soft Pink, changing to Rosy Carmine

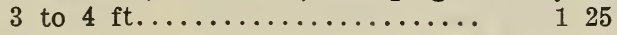

\section{New Baby Ramblers}

Rose Baby Rambler, Double Red

2 year ....................... $150 \quad 1500$

" Catharine Zeimet, Double White

2 year .................. $150 \quad 1500$ 
Per 10 Per 100

“ Jessie, Double Red

$150 \quad 1500$

“ Mrs. Taft, Double, Rosy Crimson

2 year.................. $150 \quad 1500$

\section{Wichuraiana and Hybrids}

Rosa Wichuraiana, Memorial Rose

2 year ..................... $125 \quad 1000$

3 year ................... $135 \quad 1200$

“Dorothy Perkins, Pink, Double

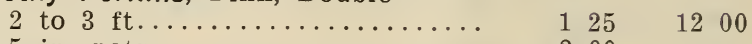

5 in. pots.............. 200

“ Evergreen Gem, White, buff in bud, Double

2 to $3 \mathrm{ft} . \ldots \ldots \ldots \ldots \ldots \ldots \ldots$

- Jersey Beauty, Buff, yellow stamens, Single

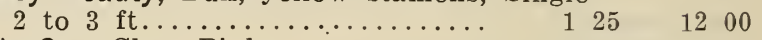

“ Lady Gay, Clear Pink

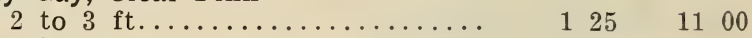

5 in. pots................ 200

“ Manda's Triumph, White, Double

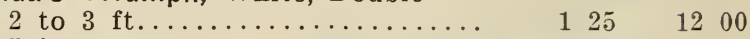

5 in. pots............... 200

“ Pink Roamer, Pink, Single

2 to $3 \mathrm{ft} \ldots \ldots \ldots \ldots \ldots \ldots \ldots$............ $125 \quad 1200$

"South Orange Perfection, White Double

2 to $3 \mathrm{ft} \ldots \ldots \ldots \ldots \ldots \ldots \ldots \ldots$. $125 \quad 1200$

“ Universal Favorite, Rose, Double

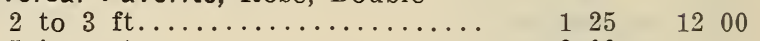

5 in. pots................ 200

\section{Roses-Hybrid Perpetual, etc.}

Assorted varieties as follows: 2 years, No. $1 \quad \$ 150$

Coquettes des Alpes, Flesh White

Frau Karl Druschki, Pure White

General Jacquiminot, Brilliant Crimson

Gruss an Teplitz, Dark Red

Hermosa, Pink

Kaiserin Auguste Victoria, Creamy White

Magna Charta, Pink Suffused with Carmine

Margaret Dickson, White, Pale Flesh Center

Mrs. John Laing, Soft Pink

Paul Neyron, Deep Rose

Persian Yellow

Prince Camille de Rohan, Velvety Crimson

Souv. de Pierre Notting, Yellow with Carmine

UIrich Brunner, Cherry Red

Sambucus aurea, Golden Elder

2 to $3 \mathrm{ft} \ldots \ldots \ldots \ldots \ldots \ldots \ldots . \ldots 100 \quad 1000$

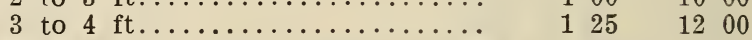

“ Canadensis, Elderberry

2 to $3 \mathrm{ft} \ldots \ldots \ldots \ldots \ldots \ldots \ldots \ldots$

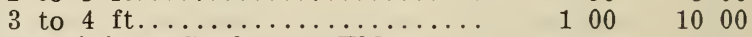

“ nigra laciniata, Cut-leaved Elder

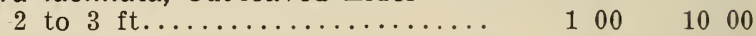

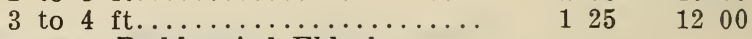

" racemosus, Red-berried Elderberry

3 to $4 \mathrm{ft} \ldots \ldots \ldots \ldots \ldots \ldots \ldots \ldots$. $125 \quad 1200$

Spiraea Anthory Waterer, Pink Dwarf

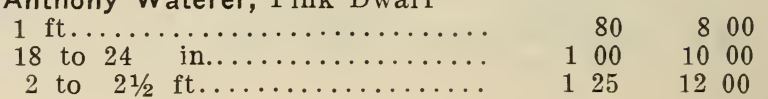


“ arguta

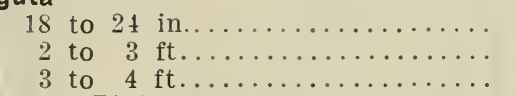

Per 10 Per 100

“ Billardi, Pink

4 to $5 \mathrm{ft} \ldots \ldots \ldots \ldots \ldots \ldots \ldots \ldots \ldots$

- callosa alba, Dwarf White

“ callosa rosea, Pink

18 to 24 in............... $100 \quad 800$

"callosa superba

18 to 24 in.............. $100 \quad 800$

“ carpinaefolia

2 to $3 \mathrm{ft} \ldots \ldots \ldots \ldots \ldots \ldots \ldots \ldots$

- Douglassi rosea

18 to 24 in ......................... $85 \quad 700$

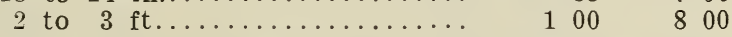

3 to $4 \mathrm{ft} \ldots \ldots \ldots \ldots \ldots \ldots \ldots \ldots \ldots 12510 \ldots$

opulifolia, White

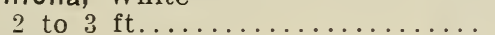

$100 \quad 900$

3 to $4 \mathrm{ft} \ldots \ldots \ldots \ldots \ldots \ldots \ldots \ldots \ldots$

“ opulifolia aurea, Golden Leaf

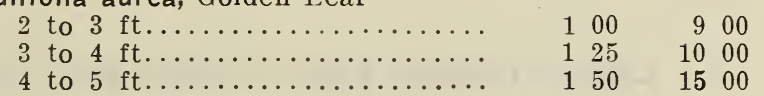

" prunifolia, Bridal Wreath

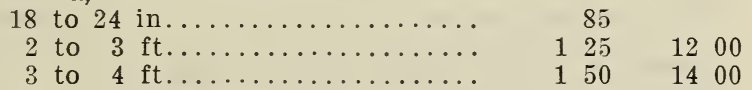

“ Reevesii, Single

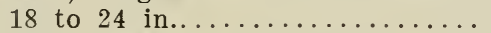

2 to $3 \mathrm{ft} \ldots \ldots \ldots \ldots \ldots \ldots \ldots$

3 to $4 \mathrm{ft} \ldots \ldots \ldots \ldots \ldots \ldots \ldots \ldots \ldots$

“Reevesii, Double
$125 \quad 1000$

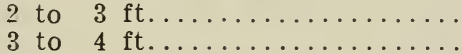

salicifolia

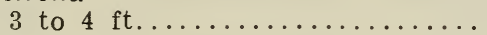

$90 \quad 800$
18

$\begin{array}{llll}1 & 25 & 9 & 00\end{array}$

$\begin{array}{llll}1 & 35 & 11 & 00\end{array}$

$150 \quad 1200$

$125 \quad 1000$

sorbifolia

2 to $3 \mathrm{ft} . \ldots \ldots \ldots \ldots \ldots \ldots \ldots \ldots \ldots \ldots 135 \quad 1300$

"Thunbergii, White

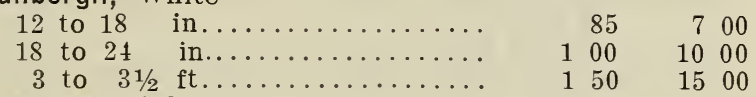

“tomentosa, Pink

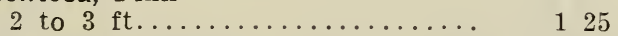

“Van Houttei

\begin{tabular}{|c|c|c|c|}
\hline 18 to & 24 in.. & 90 & 800 \\
\hline 2 to & $3 \mathrm{ft} .$. & 125 & 1000 \\
\hline to & $4 \mathrm{ft}$. & 135 & 1100 \\
\hline 4 to & $5 \mathrm{ft} \ldots \ldots \ldots \ldots \ldots \ldots$ & 150 & 1200 \\
\hline
\end{tabular}

Stephanandra flexuosa

2 to $3 \mathrm{ft} \ldots \ldots \ldots \ldots \ldots \ldots \ldots \ldots \ldots \ldots$
3 to $4 \mathrm{ft} \ldots \ldots \ldots \ldots \ldots \ldots \ldots \ldots$

Styrax Japonica

18 to 24 in................ 150

Symphoricarpus racemosus, White Snowberry

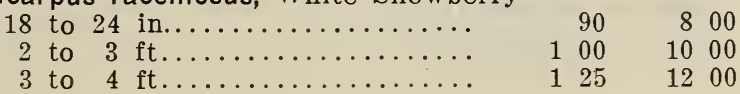


“ vulgaris, Indian Currant

Per 10 Per 100

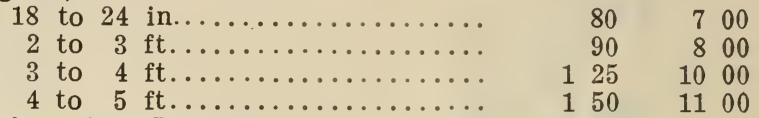

Syringa Japonica, Japanese Tree Lilac

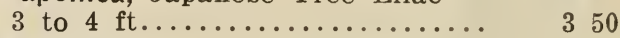

- Persica alba

2 to $3 \mathrm{ft} . \ldots \ldots \ldots \ldots \ldots \ldots \ldots \ldots \ldots \ldots$

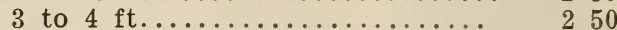

2200

"Rothomagensis (Chinensis), Red Persian

18 to 24 in.................. 125

2 to $3 \mathrm{ft} . \ldots \ldots \ldots \ldots \ldots \ldots \ldots \ldots$

1200

1500

“ villosa

3 to $4 \mathrm{ft} . \ldots \ldots \ldots \ldots \ldots \ldots \ldots .6175 \quad 1700$

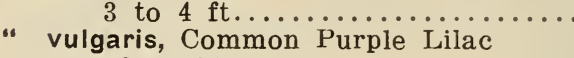

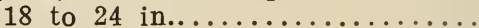

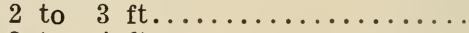

3 to $4 \mathrm{ft} . \ldots \ldots \ldots \ldots \ldots \ldots$.

“ vulgaris alba, Common White Lilac

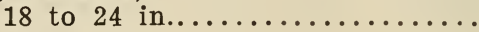

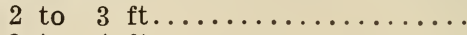

3 to $4 \mathrm{ft} . \ldots \ldots \ldots \ldots \ldots \ldots . . . .$.

$90 \quad 800$

$\begin{array}{llll}1 & 00 & 9 & 00\end{array}$

$125 \quad 1200$

$90 \quad 800$

$125 \quad 1000$

$150 \quad 1500$

\section{Choice Named Lilacs-Single and Double}

Alphonse Lavalle, Double, Large Panicles, Blue, Shaded Violet 2 to $3 \mathrm{ft} . \ldots \ldots \ldots \ldots \ldots \ldots . . . \ldots$

Charles $X$, Single, Large, Reddish Purple

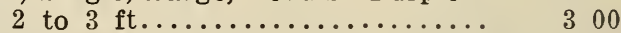

3 to $4 \mathrm{ft} . \ldots \ldots \ldots \ldots \ldots \ldots \ldots . .350$

Congo, Single. Very Large, Red

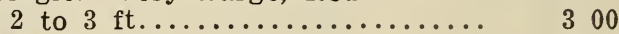

Dr. Masters, Double. Clear Lilac

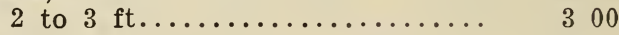

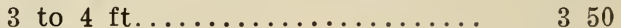

Frau Dammann, Single. White Panicles, Very Large
2 to $3 \mathrm{ft} . \ldots \ldots \ldots \ldots \ldots \ldots . \ldots . \ldots$

Ludwig Spaeth, Single. Purplish Red, Panicles Large

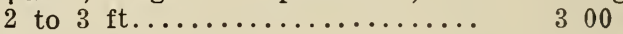

3 to $4 \mathrm{ft} . \ldots \ldots \ldots \ldots \ldots \ldots \ldots . \ldots \ldots$

Mme. Abel Chatney, Double. White. Large Panicles
2 to $3 \mathrm{ft}$
300

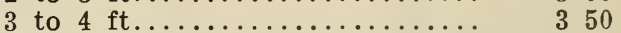

Mme. Casimir Perier, Double. Creamy White
2 to $3 \mathrm{ft}$.
300

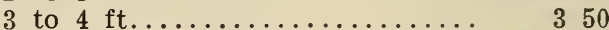

Marie Le Gray, Single. White. Panicles Large. Dwarf

2 to $3 \mathrm{ft} . \ldots \ldots \ldots \ldots \ldots . \ldots . \ldots 0$

President Grevy, Double. Blue. Flowers very large

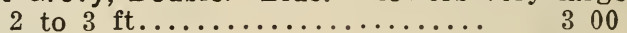

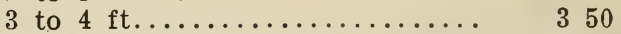

President Viger, Double. Bluish Lilac

2 to $3 \mathrm{ft} . \ldots \ldots \ldots \ldots \ldots \ldots \ldots . \ldots \ldots$

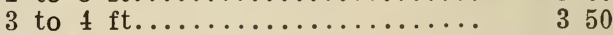

Princess Alexandra, Single. White. Large Panicles

2 to $3 \mathrm{ft} . \ldots \ldots \ldots \ldots \ldots \ldots \ldots . \ldots \ldots$

3 to $4 \mathrm{ft} . \ldots \ldots \ldots \ldots \ldots \ldots \ldots . \ldots \ldots$

Senator Volland, Double. Rosy Red. Very fine

2 to $3 \mathrm{ft} \ldots \ldots \ldots \ldots \ldots \ldots \ldots \ldots . \ldots \ldots$

3 to $4 \mathrm{ft} . \ldots \ldots \ldots \ldots \ldots \ldots \ldots \ldots \ldots$ 
Tamarix Gallica

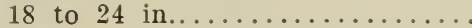

Per 10 Per 100

" Africana

“ Indica

2 to $3 \mathrm{ft} \ldots \ldots \ldots \ldots \ldots \ldots \ldots .9600$

18 to 24 in................. $80 \quad 700$

2 to $3 \mathrm{ft} . \ldots \ldots \ldots \ldots \ldots \ldots . . .60$

3 to $4 \mathrm{ft} . \ldots \ldots \ldots \ldots \ldots \ldots \ldots, \quad 125 \quad 1000$

4 to $5 \mathrm{ft} \ldots \ldots \ldots \ldots \ldots \ldots \ldots .6135 \quad 1200$

Viburnum cassinoides

12 to 18 in.................. $125 \quad 1100$

18 to 24 in................. $150 \quad 1500$

2 to $3 \mathrm{ft} . \ldots \ldots \ldots \ldots \ldots \ldots \ldots .20000$

" dentatum, Arrow Wood

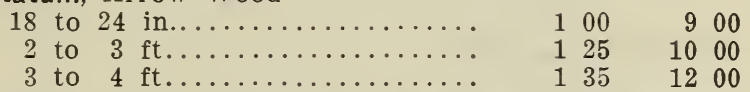

dentatum Molle

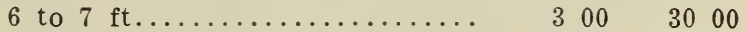

7 to $8 \mathrm{ft} \ldots \ldots \ldots \ldots \ldots \ldots \ldots .400 \quad 4000$

“ Japonicum (Sieboldi)

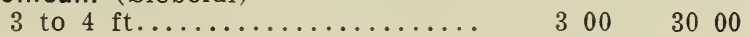

4 to $5 \mathrm{ft} . \ldots \ldots \ldots \ldots \ldots \ldots \ldots .400 \quad 400$

“ lantana, Hobble Bush

18 to 24 in................. $100 \quad 900$

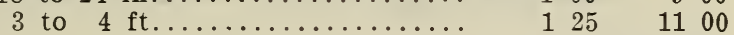

“ lentago

2 to $3 \mathrm{ft} . \ldots \ldots \ldots \ldots \ldots \ldots \ldots \ldots$

" opulus sterilis, Common Snowball

18 to 24 in $\ldots \ldots \ldots \ldots \ldots \ldots \ldots \ldots \ldots \ldots \ldots$
2 to $3 \mathrm{ft} \ldots \ldots \ldots \ldots \ldots \ldots \ldots$

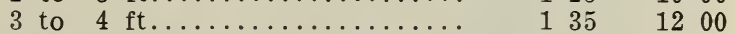

" opulus nanum, Dwarf Viburnum

8 to 10 in. bushy clumps....... $150 \quad 1500$

A very dwarf compact variety. Absolutely hardy every. where. Especially adapted for low growing edgings.

" oxycoccos (opulus), High Bush Cranberry

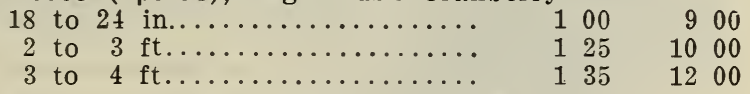

" plicatum, Japanese Snowball

18 to 24 in................. $125 \quad 1200$

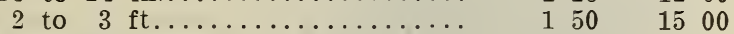

" plicatum rotundifolium

18 to 24 in....................... 125

2 to $3 \mathrm{ft} . \ldots \ldots \ldots \ldots \ldots \ldots \ldots . .6150$

" prunifolium, Black Haw

18 to 24 in................. 250

" Sieboldi-(see Japonicum)

" tomentosum

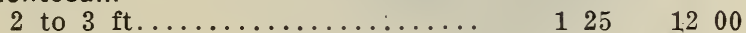

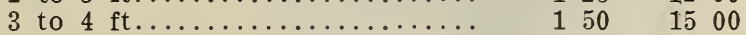

Vitex Agnus Castus, Blue

2 to $3 \mathrm{ft} \ldots \ldots \ldots \ldots \ldots \ldots \ldots \ldots \ldots$

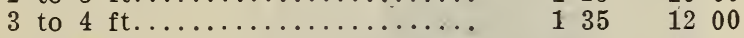

Weigela arborea, Pink

2 to $3 \mathrm{ft} . \ldots \ldots \ldots \ldots \ldots \ldots \ldots$............ $100 \quad 1000$

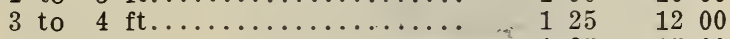

4 to $5 \mathrm{ft} . \ldots \ldots \ldots \ldots \ldots \ldots \ldots . \ldots 13500$ 
" candida, White

Per 10 Per 100

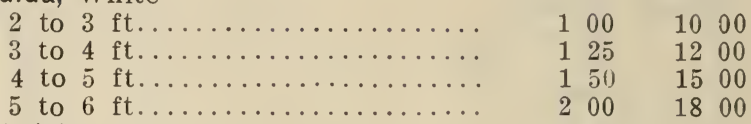

"Desboisii

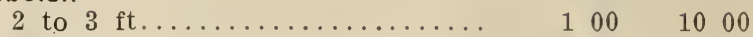

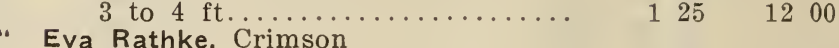

“ Eva Rathke, Crimson 100100

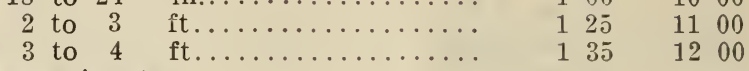

“ nana variegata

18 to 24 in.............. $125 \quad 1100$

" rosea, Pink

18 to 24 in.......................... $100 \quad 1000$

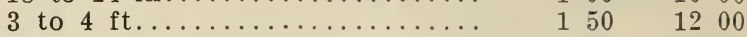

Zanthorhiza apiifolia

6 to 12 in................ $100 \quad 800$

Zanthoxylon Americana, Prickly Ash

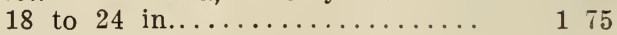

2 to 3 ft.................... 225

\section{Evergreen Shrubs}

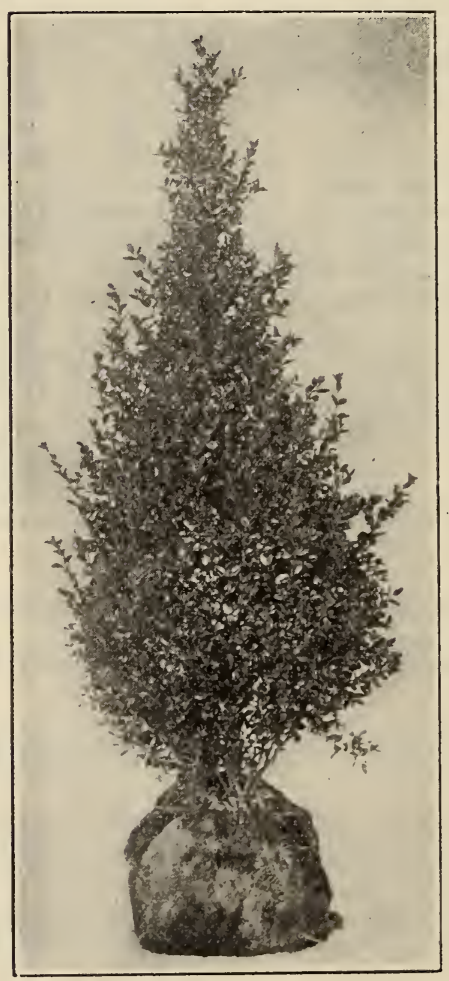

\section{Buxus Arborescens Pyramid}

We have a very fine stock of these Pyramid Box, selected in Holland by a member of our firm. They are full bushy plants, unusually broad at the base and are exceptionally suited for formal planting or for setting in vases. 
Andromeda floribunda

Per 10 Per 100

12 to 15 in. clumps.......... $10 \quad 00 \quad 10000$

" Japonica

12 to 15 in. clumps............... $750 \quad 6500$

15 to 18 in. clumps........... $1000 \quad 10000$

Azalea amoena, Evergreen Azalea

15 to 20 in. bushy clumps....... 1000

" amoena Hinodegiri

$\&$ to 10 in. clumps............ 750

Buxus arborescens, Bush Form

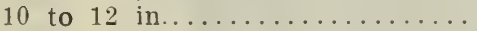

175

200

850

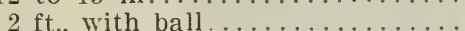

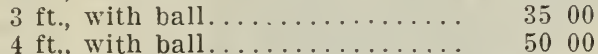

" arborescens, Pyramid

$3 \mathrm{ft}$, with ball.............. 2000

4 to $4 \frac{1}{2}$ ft., with ball........ 3000

5 to $6 \mathrm{ft}$., with ball.......... 5500

"Japonica aurea, Golden-leaved

2 ft., ball shaped............ 1000

" suffruticosa, Dwarf Box Edging

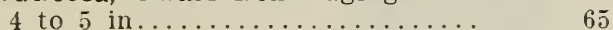

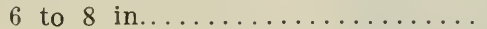

100

1500

1800

8500

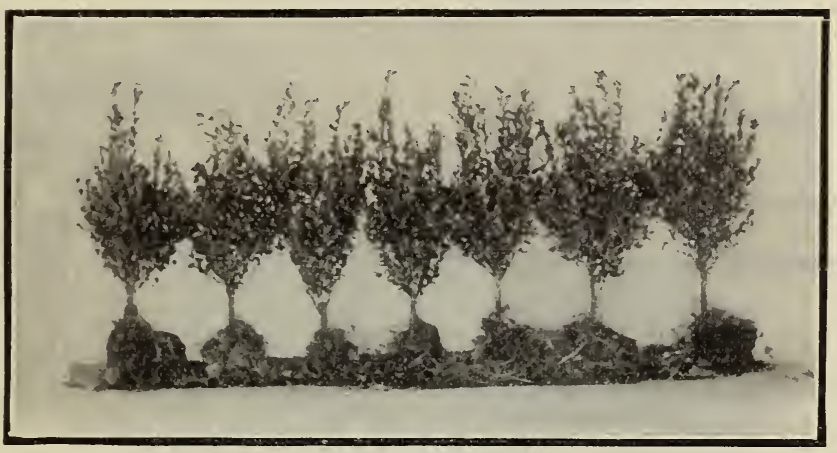

\section{Box Edging}

Our Box Edging are nice bushy transplanted plants. The 4 to 5 inch and 6 to 8 inch are the dwarf Box-suffruticosa. The Io to I 2 inch and the 12 to 15 inch are the Arborescens which have been especially grown for edging purposes where a larger edging is needed for immerliate effect. Large quantities of these are used every year and we can rarely supply all the demands of our regular trade.

Daphne cneorum, Pink

10 to 12 in. clumps, with ball... $\quad 500 \quad 4000$

llex crenata, Japanese Holly

12 to 15 in., with ball....... 250

18 in., with ball............ 850

$21 / 2$ to $3 \mathrm{ft}$. , with ball......... 1500

4 to $5 \mathrm{ft}$. pyramids, with ball.. 3000

6 to $7 \mathrm{ft}$. pyramids, with ball.. 4000

“ Aquifolia pyramidalis, English Holly

$21 / 2$ to $3 \mathrm{ft}$, with ball.......... 1250

$31 / 2$ to $4 \mathrm{ft} . \ldots \ldots \ldots \ldots \ldots \ldots \ldots . \ldots \ldots$ 


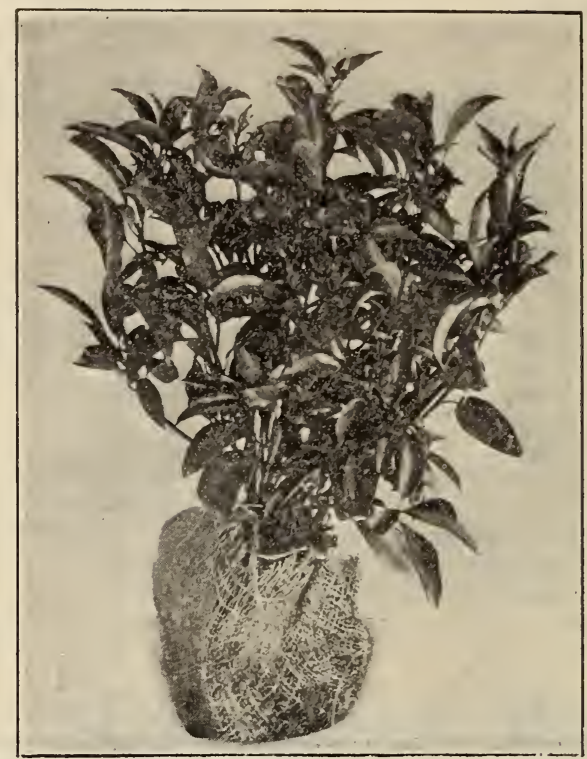

Kalmia Latifolia Native Laurel

Our stock of tliese is nursery yrown, not collected plants. They are full and bushy as shown in the illustration, which is one of the plants we are offering. Each plant is dug with a ball of earth, which is sewed in burlap as sliown in tlie picture.

Kalmia latifolia, Mt. Laurel

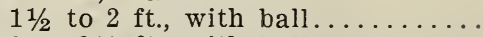

2 to $2 \frac{1}{2} \mathrm{ft}$, with ball..........

\section{Leucothaea Catesbaei}

15 in..............

Mahonia aquifolia

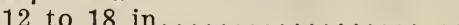

“ Japonica

18 to 24 in. clumps, with ball....

Per 10 Per 100

$650 \quad 60 \quad 00$

$850 \quad 80 \quad 00$

$350 \quad 3500$

$125 \quad 1000$

$500 \quad 5000$

Rhododendron ferrugineum

6 to 12 in. clumps, with ball.... 850

"Catawbiense

1o to 24 in. clumps, with ball... $\quad 750 \quad 7500$

"Catawbiense grandiflora

3 to $3 \frac{1}{2} \mathrm{ft}$. clumps, with ball... 2000

“ hirsutum

$1 \mathrm{ft}$. clumps, with ball........ 850

“ Maximum roseum

2 to $2 \frac{1}{2}$ ft., with ball........ $750 \quad 7500$

3 to 4 ft., with ball......... $20 \quad 00 \quad 18500$ 


\section{Rhododendrons}

Album elegans, White

Per 10 Per 100

18 to 24 in................ 850

Album grandiflorum, Flesh White

18 to 24 in.............. 850

Chas. Bagley, Crimson

18 in...................... 850

Everestianum, Lilac Rose

18 in. ............... 850

Giganteum, Cherry Red

18 in.................... 850

Lady Armstrong, Red

18 in...................... 850

Lady Cleremont, Rosy Crimson

18 in................... 850

Mrs. Millner, Rosy Crimson

18 in................... 850

Old Port, Claret Red

18 in.................... 850

$\begin{aligned} \text { Parson's grandiflorum, Bright Carmine } & \\ & 18 \text { to } 24 \text { in................... } 850\end{aligned}$

Purpureum elegans, Purplish Rose
18 to 24 in.............. 850

Roseum elegans, Rose

18 to 24 in............... 850

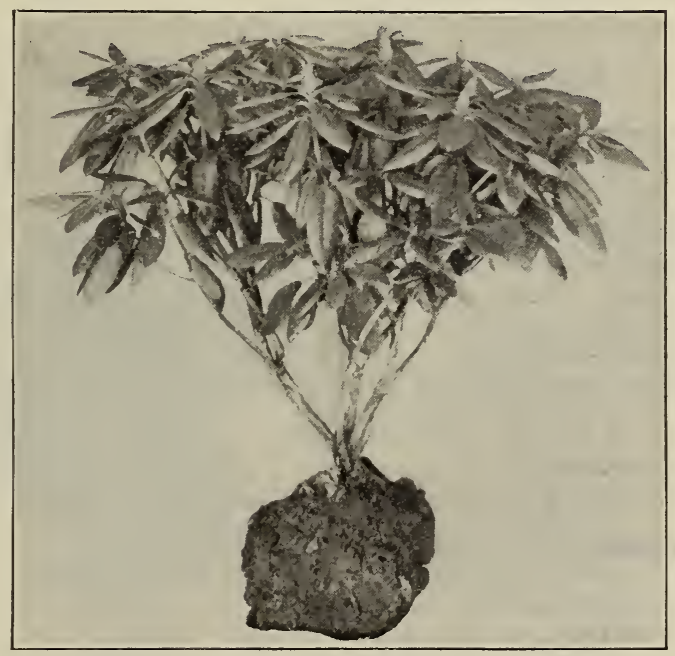

Hybrid Rhododendrons

There are many varieties of Rhododendrons not generally hardy. We handle only such varieties that have proven most satisfactory and which are recognized as "hardy", sorts. The above illustration gives an idea of the bushy character of the plants we offer and are well set with flower buds. 


\section{Evergreens}

\section{See also Evergreen Shrubs}

We feel that we cannot say too much of our evergreens. We give particular care and attention to their culture, transplanting them as frequently as may be necessary in order to secure an abundance of fibrous roots. To this end they are transplanted every two year's, and frequently sheared so that they have a good compact and shapely appearance.

All evergreens are dug with ball of earth and the ball sewed into burlap, the cost of which is included in the prices shown in the catalogue.

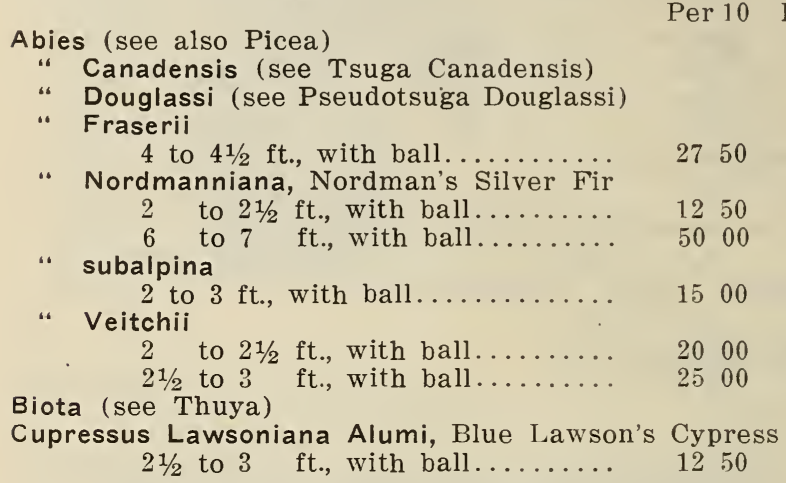

\section{Junipers for Ornamental Planting}

Throughout the entire list of Evergreens there are none so useful as the Junipers. First they have the advantage of hardiness, and adaptability to almost all soils and situations. Then they have a character all their own, and the great diversity of color of foliage makes it possible to plant an entire bed or group of them without the use of other species which may not be as hardy or satisfactory. We have gradually been extending our plantings of these Junipers until now we believe we have one of the largest and finest collections in any nursery in this country

Juniperus elegantissima Lee, Golden Cedar

“Canadensis

$21 / 2$ to 3 ft., with ball........ 1500

3 to $31 / 2$ ft., with ball......... 1750

2 to $2 \frac{1}{2}$ ft., with ball......... 1500

3 to $31 / 2$ ft................... 1750

"Canadensis aurea

18 to 24 in.............. 1500

$2 \frac{1}{2}$ to $3 \mathrm{ft}$. with ball.......... 1750

"Chinensis

$21 / 2$ to 3 ft., with ball....... 1500

.. Cannarti $3 \frac{1}{2} \mathrm{ft} . \ldots \ldots \ldots \ldots \ldots \ldots \ldots . .1750$

3 to $31 / 2$ ft................. 1750

" communis aurea, Douglass' Golden
15 to 18 in. diam., with ball..... $10 \quad 00$

"Japonica argentea variegata
2 to $21 / 2 \mathrm{ft} .$, with ball.......... 1250 


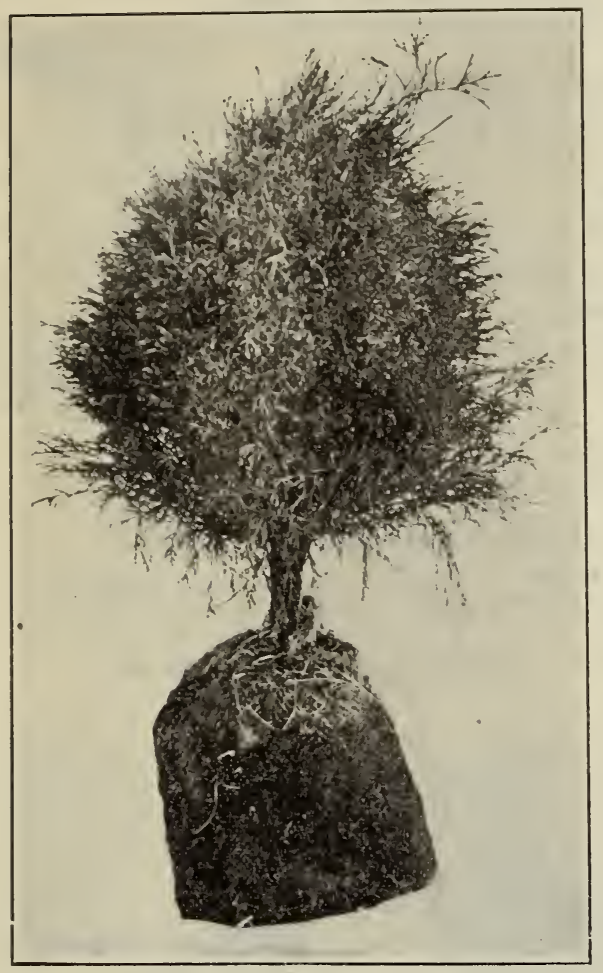

\section{Retinispora Filifera Aurea}

One of the clioicest dwarf, yol d e 11 evergreens. It lias graceful, drooping, thread like foliage, and its liabit is sliapely; and $\mathrm{thick}$ in growth. It is largely used as dwarf evergreen for planting in front of evergreen beds, though it like$w$ ise makes a very beautiful individual specimen plant. Like all golden foliaged everyreens, it holds its best color along the shore where there is great noisture in the air. We have a very large and comblete stock of this valuable plant.

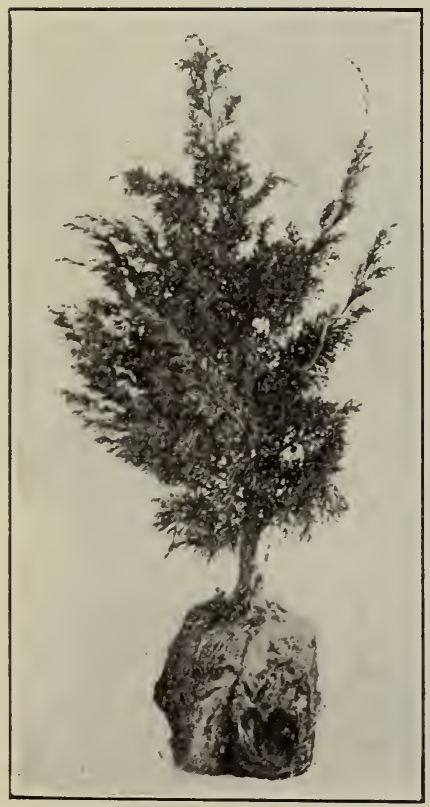

\section{Juniperus Japonica Aurea Golden Japanese Juniper}

A dwarf, golden variety of the Japanese Juniper, having habit of growth similar to the Savin Juniper. It is useful to impart color to a group of other evergreens, or for planting in the foreground of masses. Perfectly hardy and especially adapted to shore planting as the sea air tends to liven the beautiful golden color of its foliage. 
" Japonica aurea, Golden Juniper

Per 10 Per 100

2 to $2 \frac{1 / 2}{\mathrm{ft}}$, with ball....... 1500

$21 / 2$ to 3 ft., with ball....... 1750

3 to $31 / 2 \mathrm{ft}$., with ball....... 2000

- Neaboriensis

2 to $2 \frac{1}{2} \mathrm{ft}$., with ball......... 1250

$21 / 2$ to 3 ft., with ball........ 2000

3 to $3 \frac{1}{2} \mathrm{ft}$., with ball........ 2250

“ oblonga pendula

3 to $3 \frac{1}{2}$ ft., with ball......... 1750

“Pfitzeriana

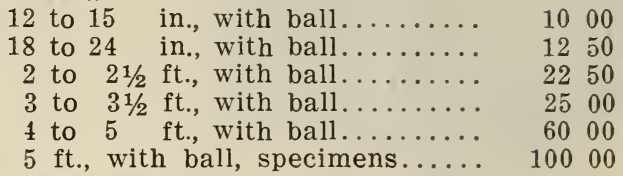

" recurva squamata

12 to 18 in., with ball ......... 1350

- Reevesiana

4 to $5 \mathrm{ft}$, with ball......... 3000

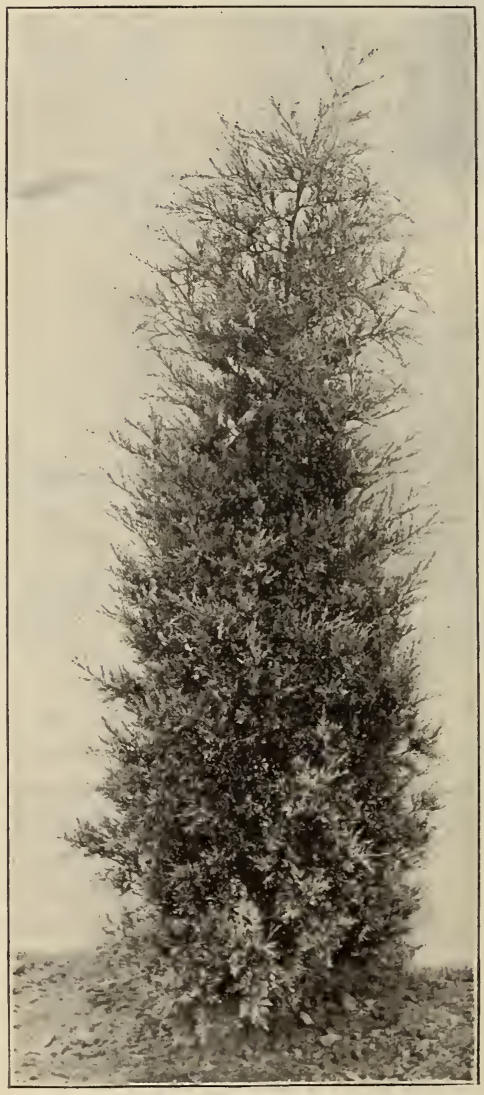

\section{Juniperus Virginiana Glauca Blue Red Cedar}

Everyone knows the Native Red Cedar, and there is no evergreen which just fills its place in landscape planting. This is a handsome variety of it, with steel blue foliage. Its hardiness extends to any part of the United States and Canada. We have probably the largest stock of this Blue Cedar in this country. 
Per 10 Per 100

- Sabina

18 to 24 in., with ball....... 350

2 to $2 \frac{1}{2} \mathrm{ft}$., with ball........ 500

"Sabina fastigiata

3 to $3 \frac{1}{2} \mathrm{ft}$., with ball......... 1750

\section{Juniperus Schottei}

A variety of Juniper similar in growth to the Red Cedar, but the color of the foliage is bright green It is of strong growth and extremely hardy. We have several hundred plants in various sizes.

"Schottei

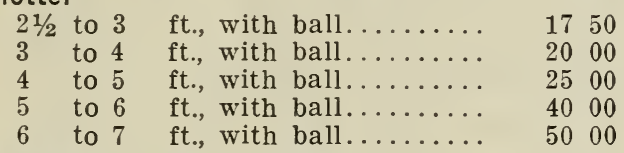

“ sinensis argentea variegata
2 to 3
ft., with ball..........
1350
3 to $3 \frac{1}{2} \mathrm{ft}$., with ball......... 1500
$31 / 2$ to 4 ft., with ball........ 1750
5 ft., with ball............ 5000

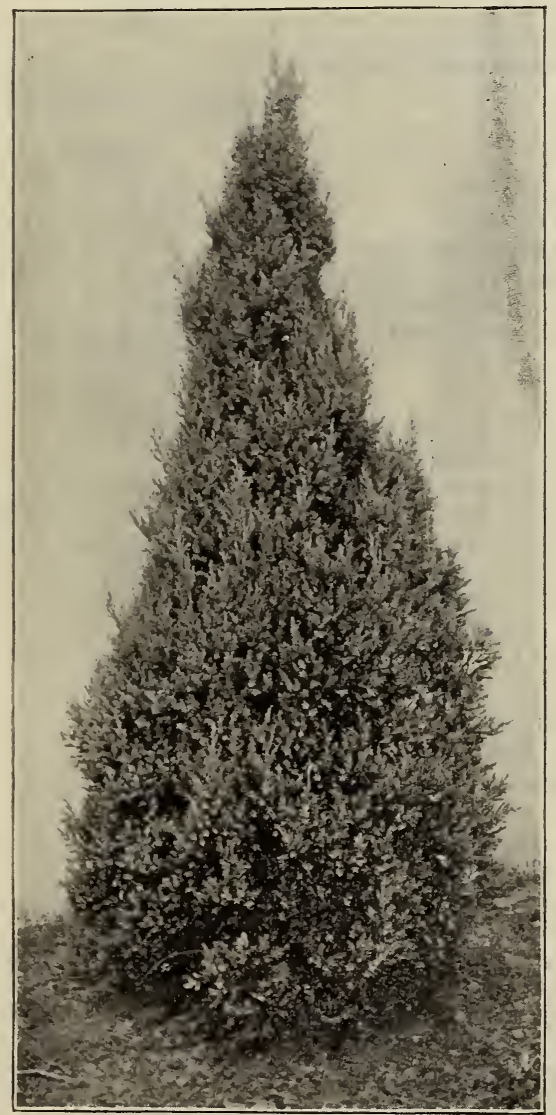

\section{Juniperus Sinensis} ArgenteaVariegata

This is one of the hardiest of the Junipers and used largely for massing in evergreen beds. It has a compact a nd symmetrical habit. The foliage is of light green color, tipped here and there with a yellowish white variegation. $\mathrm{We}$ consider this one of the best of the Junipers of $t h$ is form of growth. 
“ sinensis aurea

Per 10 Per 100

18 to 24 in., with ball........ 1250

$21 / 2$ to $3 \mathrm{ft}$, with ball........ 1500

" suecica compacta

18 to 24 in., with ball........ 350

" tamaricifolia
12 to 18 in., with ball........... 1000

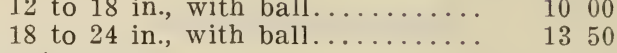

“ tripartita

3 to $3 \frac{1}{2}$ ft., with ball......... 2000

$31 / 2$ to 4 ft., with ball.......... 2250

4 to 5 ft., with ball.......... 3000

“ Virginiana, Red Cedar

3 to $3 \frac{1}{2} \mathrm{ft}$, with ball......... 1000

“ Virginiana glauca, Blue-Red Cedar

$1 \frac{1 / 2}{2}$ to 2 ft., with ball......... 1000

2 to $21 / 2$ ft., with ball......... 1350

$21 / 2$ to 3 ft., with ball......... 1500

3 to $31 / 2$ ft., with ball........ 1750

$31 / 2$ to 4 ft., with ball........ 2000

4 to $4 \frac{1}{2}$ ft., with ball........ 2500

$4 \frac{1 / 2}{}$ to 5 ft., with ball........ 3000

“. Virginiana pendula

4 to $4 \frac{1}{2} \mathrm{ft}$., with ball.......... 3000

5 to 6 ft., with ball.......... 5000

“Virginiana plumosa argentea variegata

3 to $3 \frac{1}{2} \mathrm{ft}$., with ball.......... 1500

Picea (see also Abies)

"Alcockiana

2 to 3 ft., with ball........... 1500

3 to $4 \mathrm{ft}$., with ball............ 2500

“ concolor, Colorado Silver Fir

18 to 24 in., with ball........ 1250

2 to $2 \frac{1}{2}$ ft., with ball......... 3000

3 to $31 / 2$ ft., with ball......... 4000

4 to $4 \frac{1}{2} \mathrm{ft}$., with ball.......... 5000

“ concolor violacea

7 ft., with ball.............. 6000

. excelsa, Norway Spruce

3 to $4 \mathrm{ft}$., with ball.................... 1000

4 to 5 ft., with ball.......... 1350

5 to $6 \mathrm{ft}$., with ball........... 1500

6 to $7 \mathrm{ft}$, with ball.......... 2500

7 to 8 ft., with ball.......... 3500

" excelsa inverta, Weeping Norway Spruce

3 to $4 \mathrm{ft}$, with ball............ 1750

4 to $5 \mathrm{ft}$., with ball............ 2000

“ excelsa nana compacta

12 to 15 in. broad............. 1000

“ excelsa pyramidalis, Pyramidal Norway Spruce

$3 \frac{1}{2}$ to $4 \mathrm{ft}$, with ball.......... 2000

“ Kosters glauca, Colorado Blue Spruce

2 to $21 / 2$ ft., with ball........ 2000

$21 / 2$ to 3 ft., with ball....... 2500

3 to $31 / 2$ ft., with ball......... 3000

4 to $41 / 2$ ft., with ball....... 5000

6 to 7 ft., with ball........ 10000

- Maxwelli, Dwarf Norway Spruce

12 to 15 in. broad, with ball..... 1500

" orientalis, Oriental Spruce

2 to $2 \frac{1}{2}$ ft., with ball......... 1250 
“ polita, Tiger-tail Spruce

Per 10 Per 100

2 to $2 \frac{1}{2} \mathrm{ft}$, with ball........ 1500

$21 / 2$ to 3 ft., with ball........ 2000

$5 \frac{1}{2}$ ft., with ball, specimens.... 5000

" pungens glauca pendula

5 to $6 \mathrm{ft}$., with ball, specimens.... 5000

“ Remonti, Dwarf Norway Spruce

18 to 24 in., with ball........ 1500

3 to $3 \frac{1}{2}$ ft., with ball........ 2500

Pinus cembra, Swiss Stone Pine

2 to $2 \frac{1}{2}$ ft., with ball........ 1000

4 to $4 \frac{1}{2}$ ft., with ball......... 2500

$4 \frac{1}{2}$ to 5 ft., with ball........ 3000

“ excelsa, Himalayan Pine

3 to $4 \mathrm{ft}$., with ball........... 1350

4 to 5 ft., with ball........... 1500

5 to 6 ft., with ball........... 2000

" mughus, Mt. Pine

18 to 24 in., with ball......... 1000

Pseudotsuga Douglassi, Douglas Fir

18 to 24 in., with ball......... 750

2 to 3 ft., with ball.......... 1250

3 to $4 \mathrm{ft}$, with ball......... 1750

\section{Retinispora filicoides}

\section{Retinisporas}

" filifera

$21 / 2$ to 3 ft., with ball........ 1500

7 ft., with ball............ 4000

" filifera aurea

15 to 18 in. broad, with ball... 1500

18 to 24 in., with ball........ 2250

2 to $21 / 2$ ft., with ball......... 3000

" leptoclada

$4 \frac{1}{2}$ to $5 \mathrm{ft} . \ldots \ldots \ldots \ldots \ldots \ldots . \ldots 2500$

" obtusa

18 to 24 in., with ball.......... 1000

2 to 3 ft., with ball.......... 1500

$31 / 2$ ft., with ball.............. 2000

4 to $4 \frac{1}{2}$ ft., with ball....... 2500

“ obtusa Crippsi

$2 \frac{1 / 2}{}$ to 3 ft., with ball....... 1250

" obtusa gracilis

$21 / 2$ to $3 \mathrm{ft}$., with ball.......... 1750

" obtusa gracilis erecta

$21 / 2$ to $3 \mathrm{ft}$., with ball.......... 1500

$31 / 2$ ft., with ball............... 1750

$4 \frac{1 / 2}{2}$ to $5 \mathrm{ft}$, with ball.......... 2500

“ obtusa nana

12 to 15 in., with ball......... 1000

" obtusa nana aurea

2 to $2 \frac{1}{2} \mathrm{ft}$., with ball........ 2750

$21 / 2$ to 3 ft., with ball......... 3000

“ pisifera

3 to $4 \mathrm{ft}$, with ball........... 1000

“pisifera aurea, Golden

3 to $4 \mathrm{ft}$, with ball......... 1250

6 to $7 \mathrm{ft}$., with ball.......... $30 \quad 00$

8 to $9 \mathrm{ft}$., with ball.......... 5000

10 to 12 ft., with ball......... 7000 
“plumosa

" plumosa aurea, Golden

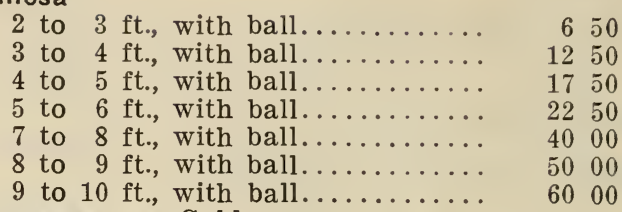

2 to $3 \mathrm{ft}$, with ball........... 850

3 to 4 ft., with ball............. 1250

4 to $5 \mathrm{ft}$, with ball.......... 1750

5 to $6 \mathrm{ft}$, with ball........... 2250

6 to $7 \mathrm{ft}$, with ball........... 3000

7 to $8 \mathrm{ft}$., with ball........... 4000

" squarrosa veitchii

5 to $6 \mathrm{ft}$, with ball............ 2250

6 to $7 \mathrm{ft}$., with ball............ 3000

7 to $8 \mathrm{ft}$., with ball........... 4000

Sciadopitys verticillata, Japanese Umbrella Pine

2 to $2 \frac{1}{2}$ ft., with ball......... 2000

Taxus adpressa stricta, Upright Japanese Yew

2 to $2 \frac{1}{2} \mathrm{ft}$., with ball.......... 1500

" baccata, English Yew

$.31 / 2$ to $4 \mathrm{ft}$, with ball......... 1500

"Canadensis, Am. Yew

18 in., with ball............. 1250

" cuspidata brevifolia

12 to 15 in., with ball.......... 1000

18 to 24 in., with ball.......... 1350

2 ft., with ball............. 2000

" Hibernica, Irish Yew

4 to $4 \frac{1}{2}$ ft., with ball.......... 2000

“ Hibernica aurea, Golden Irish Yew

2 ft., with ball.............. 1000

3 ft., with ball............. 1500

" repanda

12 to 15 in., with ball.......... 1500

18 to 24 in., with ball......... 1750

$21 / 2$ to $3 \mathrm{ft}$, with ball......... 2500

"Washingtoni aurea

$21 / 2$ ft., with ball............ 1250

Thuya Hoveyii, Hovey's Golden Arbor Vitae

18 to 24 in., with ball....... 350

2 to $21 / 2$ ft., with ball....... 500

$21 / 2$ to 3 ft., with ball....... 1000

3 to $31 / 2$ ft., with ball........ 1500

$31 / 2$ to 4 ft., with ball....... 2000

“ occidentalis, American Arbor Vitae

6 to $8 \mathrm{ft}$, with ball........... $1750 \quad 15000$

" occidentalis George Peabody, Golden Arbor Vitae

$21 / 2$ to 3 ft., with ball........ 1250

3 to $31 / 2$ ft., with ball........ 1500

4 to 5 ft............... 2000

“ occidentalis globosa, American Globe Arbor Vitae

3 to $3 \frac{1}{2} \mathrm{ft}$., with ball......... 2000

“ occidentalis pyramidalis, Pyramidal Arbor Vitae

6 to $8 \mathrm{ft}$., with ball........... $1750 \quad 15000$

" occidentalis plicata, Fern Leaf

3 to $4 \mathrm{ft}$., with ball......... 1500

“ occidentalis Vervaeneana, Golden Variegated

5 to $6 \mathrm{ft}$., with ball........... 1500

7 to $8 \mathrm{ft}$., with ball.......... 2000 
" occidentalis Victoria, Silver-tipped

18 to 24 in., with ball.......... 650

3 to $4 \mathrm{ft}$., with ball.......... 1500

4 to 5 ft., with ball......... 2000

pumila, German Globe

$21 / 2$ to $3 \mathrm{ft}$., with ball....... 750

3 to $3 \frac{1}{2}$ ft., with ball....... 1000

siberica, Siberian Arbor Vitae

18 to 24 in., with ball.......... 500

Tsuga Canadensis, Hemlock

18 to 24 in., with ball.......... 500

2 to $3 \mathrm{ft}$., with ball.......... 750

3 to $4 \mathrm{ft}$., with ball.......... 1500

$4 \frac{1}{2}$ to $5 \mathrm{ft}$. specimens, with ball. 3500

$6 \mathrm{ft}$, with ball............. 5000

"Canadensis gracilis

$5 \mathrm{ft}$., with ball.............. 3500

- Caroliniana, Carolina Hemlock

18 to 24 in., with ball......... 2000

$5 \frac{1}{2}$ to $6 \mathrm{ft}$., with ball.......... 5000

"Hookeriana

- Sieboldi

18 to 24 in., with ball.......... 1500

2 to $21 / 2 \mathrm{ft}$, with ball.......... 2500

3 to 4 ft., with ball......... 3000

\section{Vines and Climbers}

Our vines are all transplanted plants. We handle them just as we do shrubs, grow them for one year, then transplant them into regular nursery rows; give them plenty of room so that we may get a good bushy well-rooted plant.

\section{Akebia quinata}

Per 10 Per 100

18 to 24 in.................. $85 \quad 700$

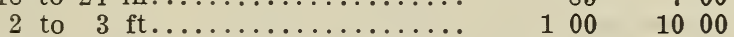

Ampelopsis Veitchii, Japan or Boston Ivy

2 and 3 years............... $100 \quad 900$

“Englemanni

2 and 3 years.............. $65 \quad 500$

4 years ................... $100 \quad 800$

"Virginica (quinquefolia), Virginia Creeper

2 and 3 years................ $65 \quad 500$

5 in. pots................. 200

Aristolochia Sipho, Dutchman's Pipe

3 to $4 \mathrm{ft} . \ldots \ldots \ldots \ldots \ldots \ldots \ldots \ldots . \ldots \ldots$

Bignonia radicans, Trumpet Creeper

18 to 24 in................. 65

2 to $3 \mathrm{ft} \ldots \ldots \ldots \ldots \ldots \ldots \ldots \ldots$

3 to $4 \mathrm{ft} \ldots \ldots \ldots \ldots \ldots \ldots \ldots \ldots . .60$

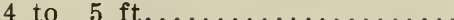

" radicans aurea, Yellow

5 in. pots.................. 250

“ radicans grandiflora

18 to 24 in............... $75 \quad 600$

Celastris orbiculatus

18 to 24 in.................... $100 \quad 900$

2 to $3 \mathrm{ft} . \ldots \ldots \ldots \ldots \ldots \ldots \ldots . \ldots 125 \quad 1000$

" scandens, Staff Vine

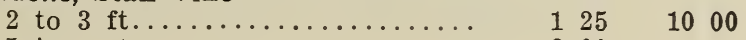

5 in. pots............... 200 
Clematis paniculata

Per 10 Per 100

3 years ............... $100 \quad 800$

\section{CLEMATIS HYBRIDS}

Strong 2 year ............ 250

LIST OF VARIETIES OF CLEMATIS

Gypsy Queen, Dark Blue

Henryii, White

Jackmanni, Purple

Lawsoniana, Light Blue

Sieboldii, Lavender

Ville de Lyon, Bright Red

Euonymus radicans, Green-leaved

6 to 12 in ................... $75 \quad 600$

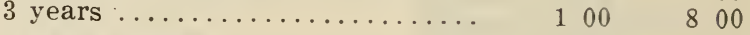

" radicans variegata

8 to 10 in................ $75 \quad 600$

Humulus lupulus, Hop-vine

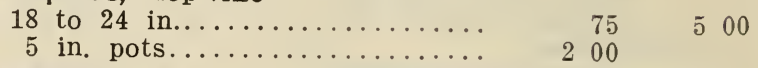

Lonicera brachypoda

5 in. pots............... $200 \quad 2000$

- brachypoda aurea

5 in. pots............... 200

“ glauca

18 to 24 in................ $100 \quad 800$

2 to $3 \mathrm{ft} . \ldots \ldots \ldots \ldots \ldots \ldots \ldots . \quad 125 \quad 1000$

“ Halleana, Hall's Honeysuckle

2 years ................. $85 \quad 700$

“ Japonica

5 in. pots................ 200

" Sullivanti

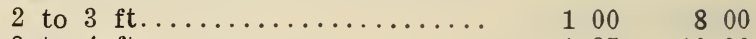

3 to $4 \mathrm{ft} \ldots \ldots \ldots \ldots \ldots \ldots \ldots \ldots \ldots \ldots$

Lycium barbarum, Matrimony Vine
18 to 24 in................

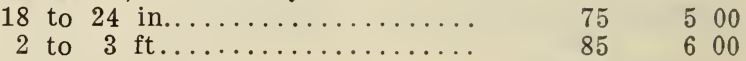

3 to $4 \mathrm{ft} . \ldots \ldots \ldots \ldots \ldots \ldots .600$

Periwinkle (see Vinca Minor)

Roses, Climbing, Creeping and Pillar (see Shrubs)

Tecoma radicans (see Bignonia radicans)

Vinca Minor, Periwinkle

3 in. pots................ $75 \quad 600$

Wistaria multijuga, Japanese Blue Wistaria

18 to 24 in. heavy clumps....... 350

- sinensis, Chinese Blue Wistaria

2 to $3 \mathrm{ft} . \ldots \ldots \ldots \ldots \ldots \ldots \ldots . \ldots \ldots$

" sinensis alba, Chinese White Wistaria

18 to 24 in................. 175

5 in. pots................ 350 


\section{Hardy Herbaceous Perennials Ornamental Grasses and Ferns}

Here is a splendid assortment of the very choicest hardy perennials for hardy gardens, borders and formal gardens.

Not small, weak, microscopic specimens, but strong, wellrooted plants, capable of producing good, quick results.

"Results the first season" is our aim always, and the general satisfaction our stock is giving is conclusive proof of its superiority.

July to September, etc., indicates the period of flowering.

Per 10 Per 100

Achillea millefolium roseum, Pink Yarrow,

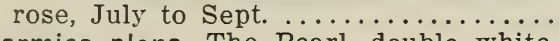

“ Ptarmica plena, The Pearl, double white,

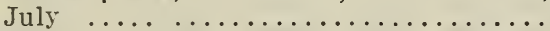

Agrostemma coronaria, Mullien $\mathrm{P}^{:} \mathrm{nk}$, crimson, June ....................... $100 \quad 800$

Ajuga genevensis, Bugle, blue, May......... $80 \quad 600$

Alyssum saxatile compactum, golden yellow, May ............................. $80 \quad 600$ Amsonia salicifolia, blue, June............. $100 \quad 800$

"tabernaemontana, clear blue, June...... $100 \quad 800$

Anchusa Italica Dropmorei, dark blue, June to Sept. ...................... 150 Anemone Japonica alba, Windflowers, White,

Sept. to Nov. ................. 100

1200

“ Japonica Alice, carmine rose, Sept. to Nov. ......................... 100

"Japonica rosea superba, rose, Sept. to

Nov. ........................ 100 Japonica Whirlwind, white, Sept. to Nov. . 100 Japonica rubra, red, Sept. to Nov. ........ 100

Anthemis tinctoria Kelwayi, Chamomile, yellow, July $\ldots \ldots \ldots \ldots \ldots \ldots \ldots \ldots \ldots \ldots \ldots \ldots \ldots \ldots \ldots \ldots$

Aquilegia Canadensis, Columbine, scarlet, May

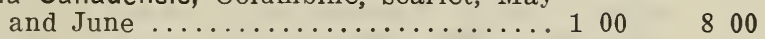

" chrysantha, yellow, June............ 100

Erskine Park Hybrids, new, various colors, May ...................... 100

“ flabellata nana alba, large white, June.... 100

" Skinneri, red and yellow, May.......... 100

“ vulgaris, blue and purple, May........... 100

"vulgaris alba, white, May.............. 100

Arabis albida, Rock Cress, white, April......... 100

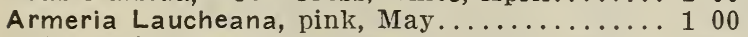

" maritima, pink, May ................. 80

“ maritima alba, Thrift, white, May........ 80

“ plantaginea, pink, May ............... 80

Artemisia Abrotanum, Old Man.............. 80

" pontica, Old Woman, silver foliage...... 80

800

800

800

Asclepias tuberosa, Butterfly Plant, orange, July .................... 100 
Aster alpina, bright purple, June and July.... 80

Per 100

" amethystinus, large pale blue, Sept. ..... 80

“ formosiissima, bright violet, Sept........ 80

“ Novae-Angliae, purple, Sept. to Oct..... 80

"Novae-Angliae alba, white, Sept. to Oct... 100

"Novae-Angliae rosea, rose, Sept........ 80

"Novi-Belgii Robert Parker, pale blue, Sept. 100

"Novi-Belgii Edna Mercia, deep rose, Sept. 100

"Novi-Belgii White Queen, white, Sept. ... 100

“ Tartaricus, light purple, late fall........ 80

Baptisia Australis, False Indigo, blue, June.... 100

Belamcanda Chinensis, Blackberry Lily, red orange, Aug. to Sept. .................. 75

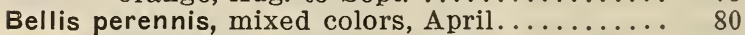

Betonica rusea, dwarf, pleasing pink, July...... 100

Bocconia cordata, Plume Poppy ........... 80

Boltonia latisquama, Starwort, pale pink, Aug.

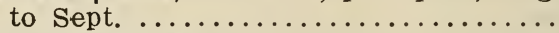

Campanula carpatica, Bellflowers, blue, July to

Sept. ....................... 100

" carpatica alba, white, July and Sept.... 100

" glomerata, blue, June................. 100

" medium, Canterbury Bells, assorted colors,

May and June ................. 100

“ persicifolia, blue, June to July.......... 100

“ persicifolia alba, white, June to July..... 100

" rotundifolia, light blue, June.......... 80

Cassia marylandica, Senna, yellow, July and August ......................... 80

Centaurea macrocephala, yellow, July.......... 100

" montana, blue, June and July............. 100

“ ruthenica, pink and white, July.......... 100

Cerastium Biebersteinii, white, April and May. 80

"tomentosum, Snow in Summer. Mouse

Ear, white, April and May.......... 80

Chrysanthemum, "Shasta Daisy" ................ 125

Clematis Davidiana, Bush Clematis, blue, Aug. . 125

“ recta, white, July................. 150

Convallaria majilis, Lily of Valley, Clumps....2 00

Coreopsis lanceolata grandiflora, Tickseed, golden yellow, summer..............

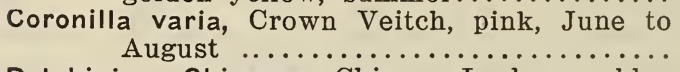

Coronilla varia, Crown Veitch, pink, June to
August $\ldots \ldots \ldots \ldots \ldots \ldots \ldots \ldots \ldots \ldots \ldots \ldots \ldots \ldots$ and white, June to August.......... 100

“ elatum, English Hybrids, Tall Larkspur, shades of blue, June to Aug. ....... 100

" formosum, Indigo, July................... 100

Dianthus barbatus, Sweet William, many colors, May and June................... 80

“ Lord Lyons, Garden Pinks, deep pink, May and June ..................... 100

" variabilis, white, maroon mark, May and June ...................... 100

Dicentra spectabilis, Bleeding Heart, pink, April and May................. 100

Dictamus fraxinella, Gas Plant, red, June..... 200

"fraxinella alba, white, June.............2 00 
Doronicum plantagineum excelsum, Leopard's

Bane, yellow, April to June......... 100

Per 100

Echinacea purpurea, Cone Flower, pink, July... 100

Eupatorium ageratoides, Hardy Ageratum, white, Sept. ................... 100

Funkia caerulea Plantain Lilies, blue, July.... 80

" cordifolia, blue, August.............. 80

" lancifolia, blue, July................ 80

“ ovata marginata, variegated foliage..... 80

“ subcordata grandiflora, white, August.... 100

" undulata variegata, white foliage...... 80

Gaillardia grandiflora, Blanket Flower, yellow

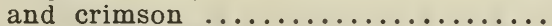

" grandiflora compacta, yellow and crimson, July to Sept................... 80

Geum Heldrichi, orange, June and July....... 100

Gypsophila cerastioides, white, June........ 100

"paniculata, Baby's Breath, white, July and August .................... 100

" repens, white, May to July.............. 100

"Rokejeka ..................... 100

Helenium autumnale superbum, Sneezewort, clear yellow, August............ 100

" grandicephalum striatum rubrum, yellow striped with brown, Aug........... 100

"Hoopesii, orange, June to July............. 100

Helianthus decapetalus multiflorus Soliel d'Or, double yellow, Aug. and Sept........ 100

" doronicoides, yellow, July and August.... 80

" giganteus, yellow, August and Sept...... 80

" laetiflorus, yellow, August and Sept...... 80

" multiflora maxima ................. 80

"Maximilliana, yellow, Sept. and Oct..... 80

" mollis, yellow, September............. 80

" orgyalis, yellow, September............... 80

" rigidus Miss Mellish, yellow, August..... 80

Heliopsis Pitcheriana, orange, June to August.. 80

" scabra major ..................... 80

Hemerocallis Dumortierii, Day Lilies, orange, June ....................... 100

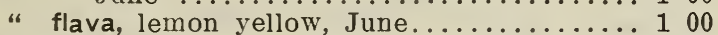

“ fulva, bronze, August.................. 80

"fulva fl. pl., bronze double, August...... 80

" Middendorfi ....................... 80

"Rutilans, orange, May and June......... 100

Heuchera sanguinea, Alum Root, red, May..... 100 Hollyhock, double, separate colors, June to Aug. 100

" single, mixed, June to August.......... 80

Iberis sempervirens, Candytuft, white, April... 80

Inula Helenium, Elecampane, yellow, July..... 100

"Brittanica ....................... 100

I ris Cengialti, deep lavender, May and June.... 80

“ florentina, Orris Root, white, May...... 80

600

600

600

600

600

600

600

600

600

600

800

800

600

600

600

800

800

800

600

$\begin{array}{ll}6 & 00\end{array}$

800

800

600

600

“ Germanica, German Iris, best assortment

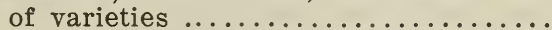

\section{LIST OF IRIS GERMANICA.}

AIEXANDER VON HUMBOLDT. Light blue self. CELESTE. Delicate blue self.

COFI.ESTINE. Pretty lavender self.

IOSFPIIINE. The best dark purple.

LADY FRANCES. Delicate lavender.

I,ADY STUMPP. Standards lavender, falls blue.

LILACEOUS. Lavender and bronze.

MAD. CHEREAU. White fringed blue.

MARIE. Lavender.

PURPTIREA. Rich purple.

SIIVER KING. Silvery white self. 
Iris laevigata (Kaempferi), Japanese Iris, in fine assorted named kinds, July......... 150 ochroleuca gigantea, sulphur yellow..... 80 pseud-acorus, yellow, May........... 80 pumila, Dwarf Iris, Various, April......... 80 Siberica orientale, Siberian Iris, indigo blue, June ................... 100

" Sibirica, "Snow Queen," pure white..... 150

“ stenophylla, blue, June............. 80

Per 100

1000

600

600

600

800

1000

600

\section{Meehan's Mallow Marvels}

PRICES FOR STRONG 2 YEAR ROOTS.

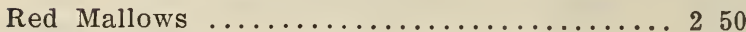

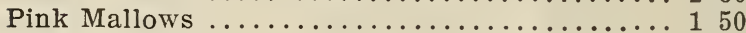

White Mallows .................... 150

PRICES FOR STRONG 3 YEAR ROOTS.

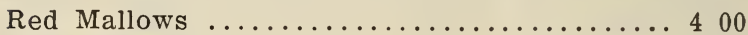

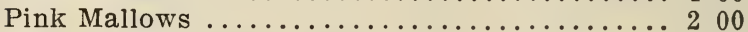

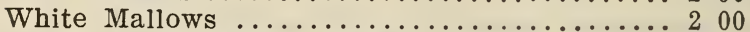

Lamium purpureum variegatum, pink, sray.... 80

Lathyrus grandiflorus, Perennial, Pea, pink and

white, June to August............. 150

Lavandula vera, Sweet Lavender, July and

August $\therefore \ldots \ldots \ldots \ldots \ldots \ldots \ldots \ldots$

Liatris pycnostachia, Blazing Star, purple, Aug.

and Sept. .................... 80

Lilium auratum, Gold-banded lily of Japan,

white spotted, July, pot grown.....2 200

$40 \quad 00$

1500

1500

600

1200

800

600

1500

800

" speciosum album, white, Aug. and Sept., pot grown ................ 200

" speciosum roseum, rose, Aug. and Sept., pots ...................... 200

“ superbum, orange red, July and Aug., pots 100

" tigrinum splendens, Tiger Lily, orange spotted, Aug., pots ............. 100

Linum perenne, Flax, blue, June........... 80

Lobelia cardinalis, Cardinal Flower, scarlet, Aug. and Sept. ................. 1 or

Lychnis chalcedonica, Scarlet Lightning, scarlet,

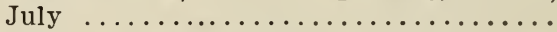

“Flos-cuculi, Ragged Robin, red, May.....

“ viscaria splendens, Catch Fly, red, July...

Lysimachia clethroides, Loosestrife, white, July

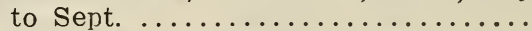

Lythrum salicaria, purple, June and July......

" Japonicum elatum, purplish red, June and July ..................... 80

" roseum superbum, purple, June and July... 100

Monarda didyma, Cambridge scarlet, Bergamot,

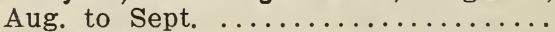

“ fistulosa alba, white, Aug. and Sept. .....

“ fistulosa purpurea, purple, Aug. and Sept...

" mollis, pink, Aug. and Sept. ............

Myosotis palustris semperflorens, Forget-MeNot, blue. April and May......... $100 \quad 800$

Nepeta Glechoma variegata, Ground Ivy, blue, April and May....................

Oenothera Missouriensis, Evening Primroses, yellow, July and Aug. ............ 
Per 10 Per 100

“ speciosa, large white, June and July..... $80 \quad 6 \quad 00$

"Youngii, yellow, June to Sept. ........ $80 \quad 600$

Paeonia officinalis rosea, fl. pl., early pink....2 $200 \quad 1500$

" officinalis rubra fl. pl., early crimson.....2 $00 \quad 1500$

" Alice, bright rose, changing to white.... $150 \quad 1200$

“ Canary, white outer petals, center yellow. $150 \quad 1200$

“ Andre Lauris, dark rose. A good standard

variety .................... $150 \quad 1200$

Delicatissima, delicate pink, fragrant ... $300 \quad 2500$

Duke of Orleans, double. Maroon Crimson $300 \quad 2500$

Festiva Maxima, pure white. Very double $150 \quad 1200$

"General Grant, deep pink, very large flowers ......................... $300 \quad 2500$

"General Schofield, deep rose, full flower.. $150 \quad 1200$

“ Leslie, crimson pink, inner petals tipped lighter ........................ $300 \quad 2500$

“Mrs. Fletcher, rosy pink, edged white ...2 $50 \quad 2000$

" Nobilissima, glowing pink, late......... $150 \quad 1200$

"Pulcherrima alba, pure white ........ $150 \quad 1200$

"Reine des Francais, outer petals rose color, straw centre ................2 $50 \quad 2000$

"Robert Burns, rose-tipped, white ....... $150 \quad 1200$

"Sapho, dark red .................... $150 \quad 1200$

Papaver nudicaule, Iceland Poppies, white, yellow and orange ................ $100 \quad 800$

“ Orientale, Oriental Poppies, crimson, June $100 \quad 800$

“ Orientale Livermore, crimson, June..... $200 \quad 1500$

" Orientaie Princess Ena, light orange salmon, June .................. $200 \quad 1500$

Pentstemon barbatus coccinea, scarlet, June... $80 \quad 600$

" diffusus, blue, June ................ $80 \quad 600$

" digitalis, Bearded Tongue, white, July.... $80 \quad 800$

Phlox amoena, pink, April ............. $80 \quad 600$

" decussata, best assortment of varieties... $100 \quad 900$

LIST OF VARIETIES OF GARDEN PHLOX.

AURORA BOREALIS. Rich orange crimson.

CARRAN DE ACHE. ROSy carmine.

CHAMPS ELYSEES. Rich purplish crimson.

CO(2UEIIC'OT. Fine pure scarlet, with deep carmine eye.

FPOPFF, Violet, bright fiers center.

INDEPENDENCF. I I arge. pure white.

LA VAGUF. Beantiful combination of rosy pink and lavender.

L'ESPERANCE. Bright lilac.

LOTHAIR. Salmon, cardinal eye.

MAD. P. LANGIER. Bright red, vermillion center.

PACHA. Deep pink.

PRINCESS LOUISE. White, small pink eye.

QUELN. Pure white.

RICIATI WAILACE. White. crimson center.

Phlox subulata rosea, Creeping Phlox, pink,

April and May....................

" subulata Sadie, lavender, April and May..

Physostegia denticulata, lilac, July and Aug...

“Virginica, Obedient Plant, lilac, Aug. and

Sept. ..................... $80 \quad 600$

“Virginica alba, white, Aug. and Sept......... $100 \quad 800$

Platycodon grandiflora, Japanese Bellflowers,

blue, July to Oct............... $100 \quad 800$

"grandiflora album, white, July to Oct..... $100 \quad 800$

“ Mariesii, blue, dwarf, July to Oct......... $100 \quad 800$

Polemonium reptans, Jacob's Ladder, blue, May $80 \quad 600$

“Richardsoni, blue, May................ $80 \quad 600$

Polygonum cuspidatum, white, August, Sept... $80 \quad 600$

Pyrethrum roseum, shades of pink and red, May

and June ................... 100 
" uliginosum, White Daisy, Sept.......... 100

Ranunculus speciosus fl. pl., Double Buttercup,

white, May and June.............. 100

Rudbeckia fulgida, Black Eyed Susan, golden, yellow, July and August............

“ laciniata, Golden Glow, yellow, Aug. and

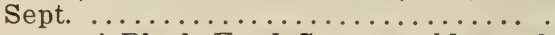

"Newmanni Black Eyed Susan, golden yellow, July and August................... 80

Salvia azurea grandiflora, blue, Aug. ........ 100

Santolina incana, Lavender Cotton.......... 80

Saponaria officinalis, Bouncing Bet, pinkish

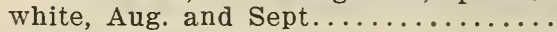

Sedum Hispanicum, pink, June and July.....

" hybridum, yellow, July and Sept. ....... 80

"Rhodiola, pink .................... 80

" sexangulare, yellow, June and July ...... 80

"spectabilis, pink, Aug. and Sept. ........ 100

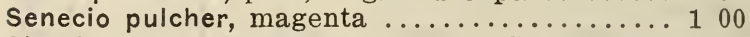

Sisyrinchlum Bermudianum, Star Grass, blue,

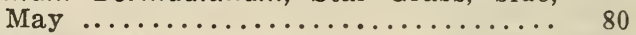

Spiraea astilboides, white, May........... 100

600

600

600

800

800

600

800

800

800

800

800

lobata-venusta, pink, June .......... 100

" multiflora compacta, white, May and June. 100

" palmatum elegans, pink, June ......... 100

" ulmaria alba plena, double white, June

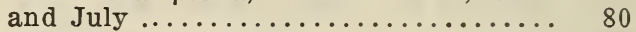

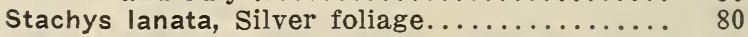

Statice latifolia, Sea Lavender. Aug. ......... 100

Stokesia cyanea, Stokes' Aster, blue, July to

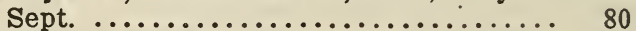

Teucrium Canadensis, pink, July to Aug...... 80

Thalictrum glaucum, handsome foliage ...... 100

Thermopsis Caroliniana, yellow, June ........ 100

Tradescantia Virginica, Spider Wort, blue, May to July ...................... 80

“Virginica alba, white, May, July ......... 80

"Virginica purpureum, purple, May to July 100

Tritoma uvaria Pfitzeri, coral, July to Oct..... 125

Valeriana officinalis, light pink, June to July... 100

. uvaria Pfitzeri, coral, July to Oct....... 125

Vernonia Jamesii, Iron Weed, purple, Aug. and Sept ......................... 100

Veronica candida, Speedwell, silvery foliage, blue flowers, June and July......... 80

" circaeoides, blue, June .............. 80

"Montana, blue, June and July........... 80

“Virginica, white, July and August....... 100

Vinca minor, Periwinkle, 3 in. pots............ 75

Viola orodata Blue, Sweet Violet, April and May 100

\section{Hardy Ferns}

4spidium acrostichoides, Christmas Fern......

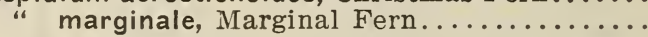

“ spinulosum .......................... wort $\ldots \ldots \ldots \ldots \ldots \ldots \ldots \ldots \ldots \ldots \ldots$

Onoclea sensibilis, Sensitive Fern............. 


\begin{tabular}{|c|c|c|}
\hline & Per 10 & Per 1 \\
\hline Osmunda cinnamomea, Cinnamon & .. 100 & \\
\hline "Claytoniana, Flowering Fern & 100 & \\
\hline " regaiis, King Fern........... & $\ldots \ldots \ldots 150$ & 12 \\
\hline Polypodium hexagonopterum & 60 & \\
\hline “ vulgare, Rock Polypod & ....................... & \\
\hline Pteris aquilina, Brake or Bracke & .......... & \\
\hline
\end{tabular}

\section{Hardy Grasses}

Bambusa Metake, Evergreen Bamboo.......2 50

Caiamagrostic stricta variegata.......... 80

Eulalia Japonica, False Pampas Grass..........2 200

“ Japonica graciliima ...............2 $00 \quad 1500$

" Japonica variegata, Erees and white striped ....................200 1500

"Japonica Zebrina, green barred with bronze, yellow ..............2 $200 \quad 1500$

Unlola latifolia, a pretty zrass with plumes, useful for rases................. $100 \quad \& 00$

\section{Ornamental Trees, Shrubs and Vines}

\section{For Planting in Nursery Rows}

TERIIS :-Five plants of any one variety at the rate quoted per ten ; twenty-five at the hundred, and two hundred and fifty at the thousand rate. Prices net. No discount. Packing charged extra. If cash accompanies the order, packing will be free.

Acer Campestre, English Cork Maple.....2 year

Per Per Per $10 \quad 100 \quad 1000$ dasycarpum, Silver Maple..... 12 to 18 in. $25 \quad 7560$ o Negundo, Box Elder.............. to 18 in. $25 \quad 75 \quad 600$ platanoides, Norway Maple.... 11/2 to $2 \mathrm{ft} .251351200$ saccharum, Sugar Maple ........... 1 year $25 \quad 1 \quad 75 \quad 1500$

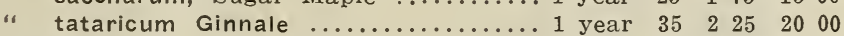

Althaea Ardens, double blue............ 1 year $35 \quad 275 \quad 2200$

" Boule de Feu, double red........... 1 year $35 \quad 275 \quad 2200$

" carnea plena, double rose........... 1 year $35 \quad 2 \quad 75 \quad 2200$

.. coelistis, single blue ............. 1 year $35 \quad 2 \quad 75 \quad 2200$

" Duc de Brabant, double red ....... 1 year $35 \quad 275 \quad 2200$

“ elegantissima, double pink ........ 1 year $\begin{array}{llllll}35 & 2 & 75 & 22 & 00\end{array}$

" folius variegata, double, variegated.. 2 year $\begin{array}{llllll}50 & 3 & 50 & 30 & 00\end{array}$

" Jean d'Arc, double, pure white..... 1 year 352752200

" rubis, single red ................. 1 year 352752200

“t totus albus, single, pure white..... 1 year $35 \quad 275 \quad 2200$

Ampelopsis Englemanni ................2 year 3522352100

“ Virginica, Virginia Creeper........2. 2 year $25 \quad 175 \quad 1500$

Baccharis halimifolia, Groundsel Shrub...2 2 year $\begin{array}{llllll}35 & 2 & 00 & 18 & 00\end{array}$

Betula alba, Eu. White Birch...........2 to $3 \mathrm{ft} . \quad 352001700$ 


\title{
Ornamental Trees, Shrubs and Vines
}

\author{
For Planting in Nursery Rows
}

\begin{tabular}{|c|c|c|c|c|}
\hline & & $\begin{array}{l}\mathrm{P} \\
10\end{array}$ & & \\
\hline alpa speciosa, Western Catalpa.. & & 75 & & \\
\hline anothus Americanus, New Jersey Tea.. 2 year & & & 20 & \\
\hline ephalanthus occidentalis, D'rf B't'n B'sh. 2 year & Зь & 235 & 21 & \\
\hline hionanthus Virginica, White Fringe.....4 4 year & 50 & 450 & 42 & \\
\hline Solutea arborescens..$\ldots \ldots \ldots \ldots \ldots \ldots$ year & 25 & 175 & 15 & \\
\hline ornus Mas., Cornelian Cherry ........2 year & 35 & 225 & 20 & 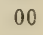 \\
\hline " sanguinea, English Dogwood .....2 year & 25 & 185 & 16 & \\
\hline otoneaster simonsi $\ldots \ldots \ldots \ldots \ldots \ldots . \ldots \ldots$ year & & 235 & 21 & \\
\hline rataegus oxycantha, Engl'h Hawt'n. $1 \frac{1}{2}$ to $2 \mathrm{ft}$. & & 185 & 16 & \\
\hline ydonia Japonica, Red Japanese Quince... 2 year & 35 & 200 & 18 & \\
\hline ytissus Laburnum, Scotch Laburnum.... 2 year & & 225 & 20 & \\
\hline eutzia cand & 5 & 2 & 0 & 0 \\
\hline .. 2 year & 5 & 225 & 20 & \\
\hline eutzia, gracilis rosea, pink........... 2 J & 5 & 225 & 20 & 0 \\
\hline Lemoinei, Dwarf, white........... 3 year & & 2 & 21 & 00 \\
\hline illa lutea $\ldots \ldots \ldots \ldots \ldots \ldots \ldots \ldots \ldots \ldots \ldots \ldots \ldots$ year & 5 & 275 & 23 & 0 \\
\hline mus Europaeus, Europ'n B'rn'g B'h. 2 year & 25 & 185 & 16 & 00 \\
\hline sima, Golden Bell.......2 2 year & 35 & 225 & 20 & 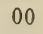 \\
\hline , Am. Whit & 25 & 75 & 6 & 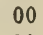 \\
\hline , Honey & 25 & 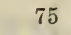 & 6 & UI \\
\hline$\ldots \ldots \ldots 1$ & a & 2 & 3 & 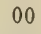 \\
\hline alnut........... 1 & 5 & 225 & 19 & 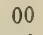 \\
\hline ata $\ldots \ldots \ldots \ldots 2$ & 5 & 225 & 20 & 00 \\
\hline ota Privet & & 1 & 5 & 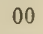 \\
\hline ovalifolium, California $\mathrm{Pr}$ & 5 & 135 & 2 & \\
\hline “ vulgaris, Common or En & 35 & 200 & 8 & 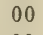 \\
\hline onicera Belgica, Belgian Hon & & 3 & 7 & \\
\hline$\ldots \ldots \ldots 2$ & 0 & 3 & 32 & 0 \\
\hline ica alba & & 3 & 0 & 00 \\
\hline ica Red, I & & 3 & 30 & \\
\hline hus aureus, $C$ & 50 & 350 & 31 & 00 \\
\hline us, Sweet Flow & 50 & 325 & 7 & 00 \\
\hline e Flow & & 2 & 22 & \\
\hline ... 12 to $18 \mathrm{in}$. & 25 & 175 & 15 & 0 \\
\hline$\ldots 12$ to 1 & 25 & & 6 & 00 \\
\hline iosa mul & 2 & 2 & 20 & PO \\
\hline$\ldots \ldots 1$ & & 225 & 0 & \\
\hline ing Wil & 3 & 235 & 1 & \\
\hline , Cut & & 2 & 22 & \\
\hline . 2 & 35 & 235 & 21 & 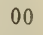 \\
\hline . 2 & & 2 & 0 & 00 \\
\hline .. 2 & 25 & 1 & 15 & 00 \\
\hline .. $2 \mathrm{y}$ & & 200 & 8 & \\
\hline aurea, Golden Le & & 3 & 6 & \\
\hline . 2 & 5 & 325 & 7 & \\
\hline flowered, white... 2 & & 200 & 18 & \\
\hline tei, white ......... 12 to $18 \mathrm{in}$. & 35 & 225 & 20 & \\
\hline & 50 & 300 & 26 & \\
\hline Ina, American Elm... & 25 & 75 & 6 & \\
\hline & 35 & 20 & 7 & \\
\hline a 91 & 50 & 3 & 28 & \\
\hline (opulus) High b'sh C'nb'ry 2 year & - & 2 & 23 & \\
\hline owbal & 5 & 3 & 30 & 10 \\
\hline ela & & 3 & 33 & \\
\hline
\end{tabular}




\section{BUDDING KNIVES}

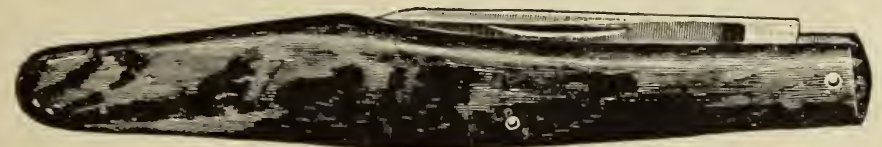

BUDDING KNIFE "D"

Next to the "Special" here is the knife for budders. Has a cocoa handle, a razor steel blade which closes, and the end of the liandle is tapered to form a wedge for raising the bark.

Price, 35c each; 6 for $\$ 2.00$

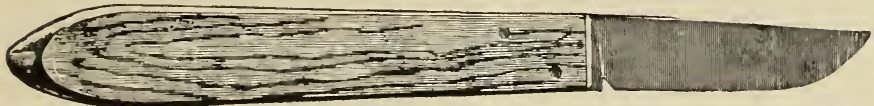

BUDDING KNIFE “ $\mathrm{C}$ ”

For anyone wanting a budding knife with a stationary blade, we recommend this kufe to contain steel of high temper equal to any razor.

Price, 25c each; 6 for $\$ 1.30$

\section{THE “HANDY” TREE CALLIPER}

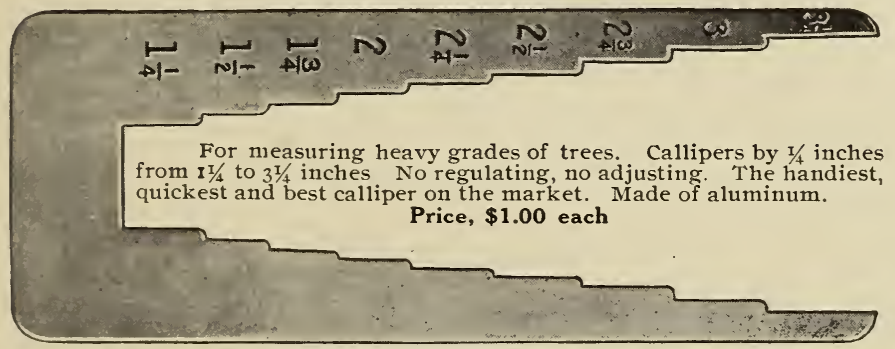

THE “HANDY JR." TREE CALLIPER

Exactly like the above, but callipers only from 2-I6 inch up to $\mathrm{I}$ inch.

Price, 65 cents each

\section{"RED STAR" BRAND RAFFIA}

"Red Star" Brand Raffia is the best all around grade of Raffia on the market. It is a guaranteed quality of good color and strength and at a most reasonable price. For general purposes it is unequaled. Its sales every year are greater than all other brands.

\section{PRICES :}

I 1b. and up@18 cents per 11). Io 1bs. and up@ 15 cents per $1 b$. 25 lbs. and 11p@12 cents per lb. 50 lbs. and up (a in cents per $1 \mathrm{~b}$.
Ioo 1bs. and up@ ro cents per 1b. I bale and up@81/2 cents per 1b. 2 bales and up @ $83 / 8$ cents per 1 b. 5 bales and up@81/4 cents per 1b. 


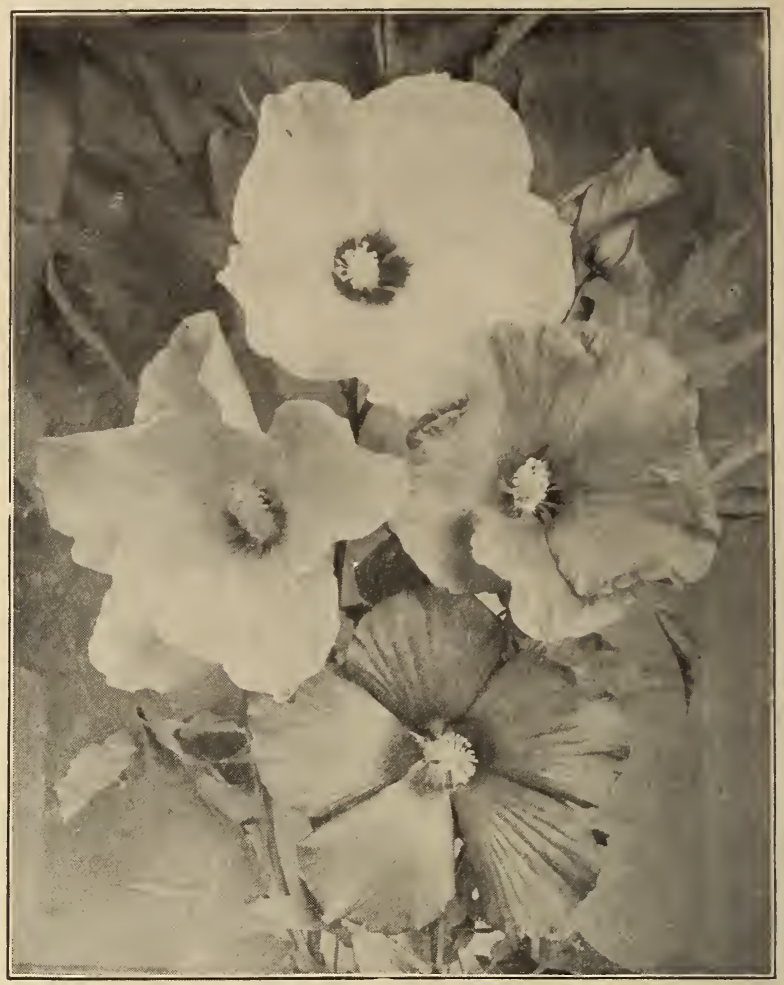

\section{Meehan's Mallow Marvels}

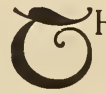

HIS plant has become so widely distributed since we introduced it several years ago that it seems unnecessary to discourse upon its merits at this time. It is a pedigree, being a cross between the southern scarlet Hibiscus and our native swamp Mallow.

It makes a vigorous growth-strong roots making a bushy clump five to seven feet in one season and blooming profusely from midsummer to frost. Being an herbaceous plant it dies to the ground in the fall, shooting from the root again the following spring.

The flowers measure from eight to twelve inches in diameter, and are sold in separate colors, in red, pink and white.

The plant is extremely hardy, having been tested and grown in all parts of the United States and Canada.

It grows naturally in moist ground but thrives equally as well in any gond, rich soil.

\section{THOMAS MEEHAN \& SONS Wholesale Nurserymen DRESHER, PENNA.}

